\title{
مشكلات مرحلة المراهقة وأثرها على الاستقرار الأسري \\ (دراسة وصفية على عينة من أباء وأمهات طراهقين بهحافظة جده)
}

\section{Adolescence Problems and their Impact on Family Stability}

\section{(Descriptive Study on a Sample of Parents of Adolescents in Jeddah Governorate)}

\author{
إعداد الباحث/ محمد سعيد حسن الزهراني \\ ماجستير توجيه و إصلاح أسري، قسم علم الاجتماع و الخدمة الاجتماعية، كلية الآداب و العلوم الإنسانية، جامعة الملك عبد \\ العزيز، المملكة العربية السعودية
}

Email: mshz93@hotmail.com

الملخص:

هدفت الدر اسة الى التعرف على مشكلات مرحلة المراهقة و أثر هـا على الاستقرار الأسري، والتي كان من أهمها مشكلات المر اهـق مـع أفر اد أسـرته مـن وجهـة نظـر الو الدين، بالإضـافة للمشكلات (النفسية ــ الاجتماعيـة ــ الدر اسـية) التي تواجـهـ المر اهقين. وقد اعتمدت الدر اسـة على منهج المسـح الاجتمـاعي كدر اسـة وصفية بأسلوب العينـة، واستخدمت الاستبانة كأداة رئيسية لجمع البيانات من عينة عشو ائية بلغت (226) من آبـاء و أمهات لمر اهقين بمحافظة جدة، وكان من أهم نتائج الدر اسـة أنها أظهرت أهم مشكلات المر اهق مـع افر اد أسرته من وجهة نظر الو الدين أن المر اهق ينفرد بنفسـه لوقت طويل، ويثور ويغضب لأتفه الأسباب، وأن أهم المشكلات النفسية التي تو اجه المر اهقين من وجهة نظر الو الدين جـاءت بدرجـة متوسطة أن اهن المر اهق يعـاني من سـرعة الانفعـال و الغضب، ويخـاف من انتقاد الآخرين لـه، ومن أهم المشكلات الاجتماعيـة التي تواجـهـ

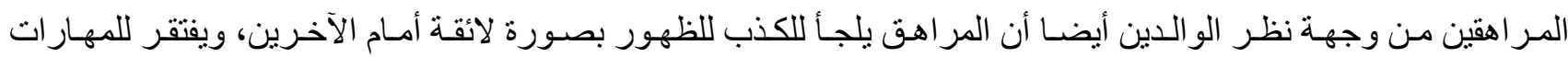
الاجتماعية، كذلك أظهرت النتائج أن أهم المشكلات الدراسية التي تواجه المر اهقين من وجهة نظر الو الدين أن المر اهق يعجز عن تتظيم وتخصيص وقت للار اسة، وقليل الاهتمام بالدروس و الواجبات المنزلية، كمـا أظهرت النتائج أن أهم الآثار المنرتبـة على الاستقر ار الأسري من مشكلات مرحلة المر اهقة في تجنب إبني / إبنتي الحديث معي عن مشـاكله الخاصـة، وفي استخدام إبني / إبنتي الهو اتف الذكية يؤثر في استقر ارنا الاسري ـ وقد أوصت الدر اسـة أنه يجب على الآبـاء و الأمهات أن يكون لديهم المعرفة والفهم لمشاعر أبنائهم في مرحلة المر اهقة وأن يأخذوها بعين الاعتبار عند التعامل معهم. الكلمات المفتاحية: مرحلة المر اهقة، الاستقرار الأسري، مشكلات، المر اهقين، محافظة جدة. 


\section{Adolescence Problems and their Impact on Family Stability}

(Descriptive Study on a Sample of Parents of Adolescents in Jeddah Governorate)

\section{Abstract:}

The study aimed to identify the problems of adolescence and their impact on family stability, the most important of which was the adolescent's problems with his family members from the parents' point of view, in addition to the (psychological - social - academic) problems facing adolescents. The study relied on the social survey method as a descriptive study using the sample method, and the questionnaire was used as a main tool for collecting data from a random sample of (226) parents of adolescents in Jeddah Governorate. The teenager is alone for a long time, rages and gets angry for the most trivial reasons, and that the most important psychological problems facing adolescents from the parents' point of view came to a moderate degree that the teenager suffers from irritability and anger, and is afraid of others criticizing him, and one of the most important social problems facing adolescents from the parents' point of view Also, the adolescent resorts to lying to appear appropriately in front of others, and lacks social skills. The results also showed that the most important academic problems facing adolescents from the parents' point of view are that the teenager is unable to organize and allocate time for study, and has little interest in lessons and homework. The results also showed that the most important effects the consequences of family stability are among the problems of adolescence in my son/daughter's avoidance of talking to me about his own problems, and my son/daughter's use of smart phones Affect our family stability. The study recommended that parents should have knowledge and understanding of the feelings of their children in adolescence and take them into consideration when dealing with them.

Keywords: adolescence stage, family stability, problems, adolescents, Jeddah governorate 
الأسرة هي محور الدر اسات الاجتماعية في علم الاجتماع والانثروبولوجياو علم النفس بشكل عام، فالأسرة هي النواة الرئيسـة والنظـام الاجتمـاعي الأساسـي للمتمـع، لذا يعد الاستقر ار الأسـري من أهم المو اضيع الخاصـة بالأسرة والتي لاقت اهنماماً بالغاً من المختصدين وتحديداً الغربيين، كمـا أفردوا لها العديد من الدر اسـات الاجتماعية و النفسية، كمـا يعد الاستقرار الأسري أحد الجوانب الأساسية التي تعتمد عليها الدراسات الأسرية، فقياس الاستقرار الأسري ودرجته أحد اهتمامـات الباحثين في الثئون الأسرية و التي تقوم بتحديد مدى تكيف الأسرة مع المعطيات ومحبطها الاجتماعي و الثقافي الذي يعيش به الفرد وبين

مقدار الضغوط الاجتماعية وتأثير ها على الفرد سو اء بصورة مباشرة أو غير مباشرة (الكندري، 2008 : 92).

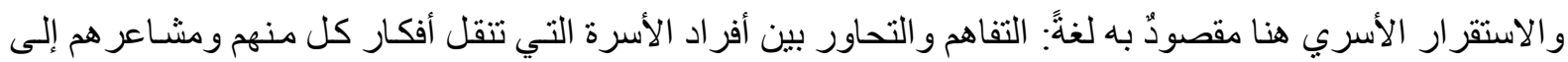
الآخرين داخل الأسرة، حيث تعمل هذه العلاقة على جعل جميع أفر اد الأسرة سعداء في حياتهم الأسرية، كما تزيد التر ابط بين أفر ادها وتساهم في استمر ارها، ومن المؤكد أن الاستقرار الأسري الجيد بين الأبناء والأهل يساعد على تماسك الأسرة ويحافظ

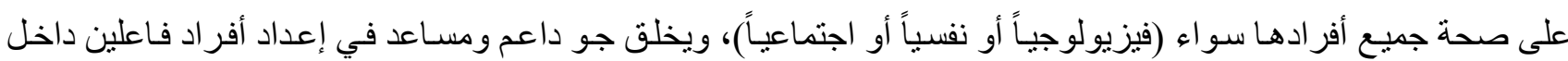
المجتمع (كريمة، 2020، 458).

إن مرحلة المر اهقة التي يمر بها الفرد تقع بين مرحلتي الطفولـة المتأخرة و الرشد، وتبدأ بتخطي بلوغ الحلم و اكتمال النضج الجنسي، حيث يتحول جسم الطفل أو الطفلة إلى جسم رجل أو امر أة، ويحدث ذلك في سن الحاديـة عثر تقريبـاً على بلى الأقل بالنسبة للإناث، وتمتد عشرة سنوات تقريباً فنتتهي في العشرين أو مـا بعدها، وهي كما يرى البعض من أكثر مر احل

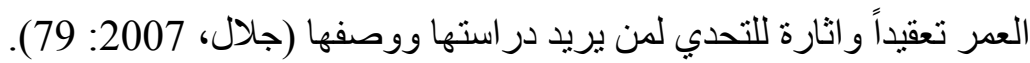
ولقد ركز علماء الاجتماع في تعريفهم لمرحلة المر اهقة على مفهومي الدور Role و المكانة Status، حيث يرون أنها تللك المرحلة التي يصل فيها الفرد لمكانته في البناء الاجتماعي ويؤدي أدوارًا اجتماعية معينة بسنطيع من خلالها المسـاهمة في البناء الاجتماعي. وقد تنشأ لدي المر اهق بعض الاضطر ابات السلوكية، ويعجز أيضاً عن التكيف مـع المجتمع الذي يعيش فيه، لأنها يختبر في بداية انتقاله من مرحلة الطفولة إلى مرحلة الرشد بتغير ات نفسية وجسدية قد لا يسنطيع فهمها أو التكيف معها، كما يعتبر كثير من المختصين فترة المر اهقة بأنها فترة ميلاد جديد، حيث تولد في هذه المرحلة الخصائص الإنسانية الكاملة، وتكون الحياة الانفعالية للمر اهق في صورة حالات متناقضة، فمن الحيوية و النشاط إلى الخمول و الكسل، ومن المرح إلى الحزن، ومن الرقـة إلى الفظاظة، ولذا حتى تسلم وتأمن الأسرة بقدر كبير من الآثار الناجمة عن المر اهقة، فلابد لها أن تتعرف على طرق فئ معاملـة المر اهق بصورة تتماثى من هذه التغير ات الجديدة للمر اهق ومع منطلباته ودو افعه (منصور و آخرون، 1410هـ : 125). وفي تللك المرحلة الحرجة من حياة المر اهقين يقع الدور الكبير في رعايـة الأبناء على الوالدين، حيث يتأثر المر اهق

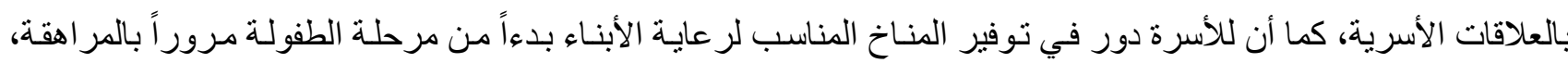
فالأسرة هي النواة الأولى في المجتمع التي تقوم بالتنشئة الاجتماعية لأبنائها، بشكل منو ازن وخالي من الاضطر ابات و المشـاكل

$$
\text { السلوكية (أبو منديل، 2016). }
$$


المجلة الدولية لنشر البحوث والدراسات

International Journal of Research and Studies Publishing
كلجلد الثالث - الإصدار السادس والعشرون تأريخ الإصدار: 20 ديسمبر 2021م

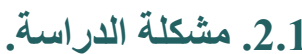

إن أداء الأسرة لوظائفها و أدو ار ها المتعددة بعد قضية أساسية ترنبط باستقر ارها وتكيفها السليم مـع بيئتها المجتمعية المحيطة، فأساس عملية الاستقر ار هو التكيف الاجتماعي والصحي للأفراد وللأسرة، ولوجود علاقات أسرية بين أفر اد الأسرة الو احدة بالغ الأهمية أيضاً، حيث من الممكن أن تخلق هذه العلاقات داخل نطاق الأسرة مناخـاً اجتماعياً مميزاً يعزز من مفهوم الاستقرار (الكندري، 2008).

ولذلك فمن الواجب على الآباء والأمهات أن يمتلكوا الحد الأدنى المطلوب من الثقافة التربويـة، لمعرفة كيفية التعامل مع مثل هذه المشاكل حتى تمر هذه المرحلة بسلام ، وون المعروف أن مرحلة المر اهقة لها تأثنير كبير في حياة الفرد وسلوكه النفسي و الاجتماعي، لذا كان وجوبًا على الأسرة والمربين الاهتمام بـالمر اهقين وبمشكلاتهم ، فعلى سبيل المثال لا الحصر قد نجد المر اهق في بعض الأحيان على مستوى الأسرة مندفع أو منفعل، وأحيانـا أخرى نجده رافض للنصبحة و التوجيه وربمـا يميل للعزلة و عدم المشاركة في أي نشاط، و أحياناً يميل إلى السلوك العدو اني الذي ربمـا يدفع المحيطين بـه من أفراد الاسرة المعاملة بالمثل، كما تعد علاقتهم مع آبائهم و التحدي بينهم من أكثر مشـاكل المر اهقين شيو عاً، حيث يبحث الابن عن الحريـة المطلقة فيظلل يسعى بوجدانه لبلوغ مرحلة المر اهقة لأنها السبيل الوحيد لتحقيق ذلك، لذلك يرى في سلطة الو الدين تقييد لحريته ويسعى دائما للتحرر من السلطة وبلوغ موقع المسئولية والاستقلالية، وأن ما يضعه الآباء من قيود وقو اعد ومر اقبة مستمرة لـه يحد من تطلعاته.

و عليهه ومن خـلال العرض السـابق فـان الدر اسـة الحاليـة تتضـمن مشكلات مرحلـة المر اهقة و أثر هـا على الاستقر ار الأسري عند عبنة من أباء و أمهات لمر اهقين بمحافظة جده.

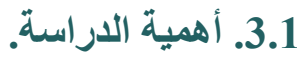
تبرز أهمية الدر اسة من ناحيتين هما:

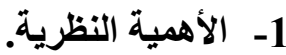

- - تكمن أهميـة الدر اسـة في عدة جو انب أهمها ندرة الدراسـات الاجتماعية و الأسرية في مجال الاستقر ار الأسرب بشكل خاص، فالدر اسـات العربيـة والمحلية في هذا الجانب المهم في حباة الأسـرة قليل، حيث وجدت افتقار المكتبة العربيـة للار اسات في جانب الاستقر ار الاسري. - - أهميـة المرحلة العمريـة التـي تتناولها الدر اسـة (مرحلة المر اهقة) ومـا يتخلاهـا من تغير ات وتحولات بيولوجيـة ونفسية و عقلية واجتماعية حيث تعد مرحلة انتقالية مهمة في حياة الانسان.

2- 2 - الأهمية التطبيقية.

- - قد تسهم نتائج الدر اسـة في معرفة منطلبـات تلكل المرحلة و اكسـاب الو الدين اتجاهـات ايجابية في التعامل مـع المر اهقين خلال تلك المرحلة الحرجة.

- - قد تسهم نتائج الدر اسة في مساعدة الباحثين في المجال التربوي و النفسي و الاجتماعي في التعرف على خصـائص مرحلة المر اهقة وتنمية الجانب الوقائي ووضع الخطط العلاجية في حال لزم الامر. 
المجلة الدولية لنشر البحوث والدراسات

International Journal of Research and Studies Publishing
المجلد الثالث - الإصدار السادس والعشرون تأريخ الإصدار: 20 ديسمبر 2021م

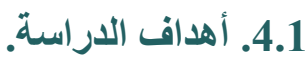

تهدف الاراسة إلى تحقيق ما يلي:

الهـف الرئيسي هو معرفة الاثار المترتبة على الاستقرار الاسري من مشكلات مرحلة المراهقة ومن هنـا تتفرع لنـا الأهداف

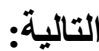

1. التعرف على أهم مشكلات المر اهق مع أفر اد أسرته من وجهة نظر الو الدين.

2. التعرف على المشكلات النفسية التي نو اجه المر اهقين من وجهة نظر الوالدين. 3. التعرف على المشكلات الاجتماعية التي تواجه المر اهقين من وجهة نظر الوالدين.

4. التعرف على المشكلات الدر اسية التي تواجه المر اهقين من وجهة نظر الو الدين.

5. التعرف على مدى تأثثر مشكلات مرحلة المر اهقة على الاستقر ار الاسري.

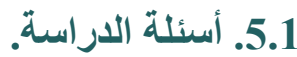

جاءت هذه الاراسة للإجابة على الأسئلة التالية:

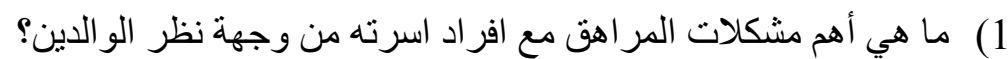

2) ما هي المشكلات النفسية التي تو اجه المر اهقين من وجهة نظر الو الدين؟

3) ما هي المشكلات الاجتماعية التي تو اجه المر اهقين من وجهة نظر الو الدين؟

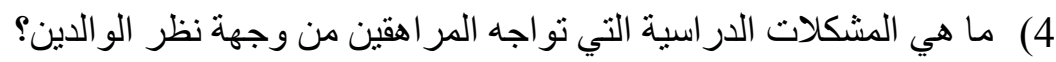

5) ما هي الاثار المترتبة على الاستقرار الاسري من مشكلات مرحلة المر اهقة؟

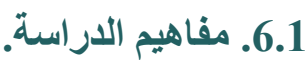

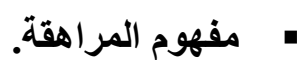

يعرف قاموس الخدمة الاجتماعية المر اهقة بأنها " هي فترة في دورة حياة الإنسان بين الطفولة وسن البلوغ، وهي تبدأ من سـن الحلم، وتشمل المرحلة المبكرة من سن البلوغ، كمـا ترتبط المر اهقة بسمات سلوكية تميز الفرد في هذه المرحلة" (السكري، 1420 هـ :20).

وتعرف مرحلة المر اهقة بأنها " المرحلة التي تبدأ بالبلوغ وتنتهي بدخول المر اهقين مرحلة الرشد وفق المحاكاة التي يحددها المجتمع حيث نجد أن بعض المجتمعات تحدد سن الرشد بثمانية عثر سنة في حين ترى مجتمعات أخرى أن سن واحد

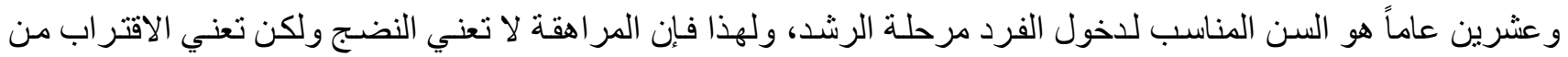
النضج الجسمي و العقلي و النفسي و الاجتماعي بطريقة تدريجية " (أبو جادو، 4004: ويعرف الباحث مرحلة المر اهقة اجر ائياً: بانها مرحلة من النمو منوسطة بين سن البلوغ وسن الرشد تحيط بها عدة مشكلات وأزمات ناثئة عن التغير ات الفسيولوجية و النتأثير ات النفسية والاجنماعية. 
يعرف الاستقر ار اصطلاحاً بأنـه " مـا يعني الإبقاء على الواقع كما هو كائن، أي انتظلام حركة المجتمع في أنماط

معينة، و التي تضبط حركة المجتمع وبما يتحقق من خلال المشاركة وينتفي في حالة الصر اع" (كريمة، 2020 : 461).

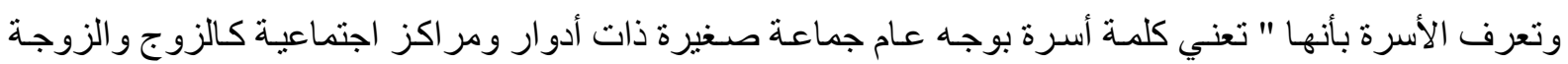
و الأب و الأم و الابناء برتبطون برباط شر عي أقره وأعرف به المجتمع لجانب رابطة الدم والزواج و التبني وتتشترك في سكن

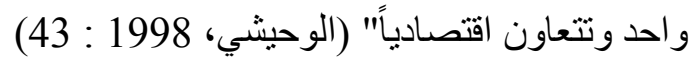
ويعرف الباحث الاستقرار الأسري إجر ائياً: بأنه نظام تتحدد فيه الأدوار وتتغير بتغير مر احل النمو التي يعيشها أفراد الاسرة من ناحية، وبالتغير ات في دورة حياة الأسرة من ناحية أخرى، وتعبش في حالـة مستقرة من الهدوء و الثبات و السكينة بعيدة عن الصر اعات الداخلية و المشكلات.

\section{2. الخلقية النظرية للار استة} 1.2. النظريات المفسرة لمرحلة المراهقة النظرية لها عدد من المعاني المختلفة باختلاف الفرع التي تستخدم به هذه الكلمة، أما النظرية الاجتماعية تتشير إلى استعمال مجرد في أغلب الأحيان لهياكل مركبة نظرية لنَوضيح وتَحليل أنماط الحياة الاجتماعية، وفهم الكثير من الظواهر بهر

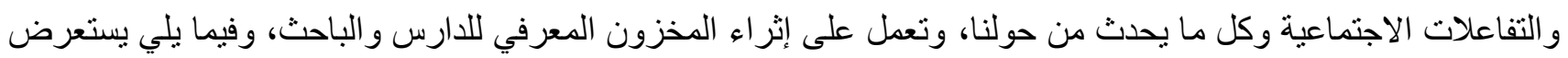
الباحث أهم النظريات المفسرة لمرحلة المر اهقة كما يلي:

Stanely Hall 1 نظرية ستانلي هول وتتلخص وجهـة نظر هـول التـي عرفت بنظريـة " الثـدة والمحن" في أن المر اهقة مرحلـة تغير شـيد أو مبلاد جديد

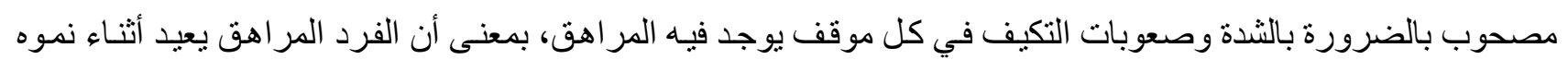
الثخصي وتطوره الارتقائي التراث الثقافي، واختبار ات الجنس البشري، ومختلف مر احل تطوره ونموه، ولكن بشكل ملخص، وبتعبير آخر ، يتمثل ملخص هذه النظريـة في " أن الإنسـان خلال مر احل نموهو وتطوره يعيد تاريخ الجنس البشري، فالطفل الصغير إلى حدود سن الرابعة عشر تقريباً يجتاز طور اً من النمو شبيه بالمرحلة البدائية في تاريخ الإنسانية، وهو أيضـا قريب من الحيوان كنوع، لكن معظم المهار ات الحسية الحركية في هذا الطور تسعى إلى حفظ ذاته، وفترة المر اهقة بدور ها فترة مماثلة للفترة التاريخية من ماضي الإنسان، وهي الفترة التي كان يعمل من خلالها للارتقاء بنفسه من الحياة البدائية إلى صور و أنثكال الحياة المجتمعية الأكثر تحضر اً. ويعني هذا أن الإنسان " منذ ميلاده إلى اكتمال نضجه يميل إلى المرور بـالأدوار التي مر بها تطور الحضارة البشرية منذ ظهور الإنسان إلى الآن "، ويمر الإنسـان في هذه الأدوار مروراً عاماً (القوصي، 1987

2- 2 - نظرية التعلم الاجتماعي. يعتمد أصحاب هذه النظريـة بدرجة كبيرة على نظريات علم الاجتمـاع و النتائج التي توصلت اليها البحوث الاجتماعية، ودر اسات الانثروبولوجيا ويعتقدون بأن الأطفال يتعلمون من خلال عملية تعليمية معقدة، 
بصورة مباشرة أو غير مباشرة مما يشجعهم على مطابقة سلوكهم مع السلوك المتوقع ضمن حضارتهم، فعلى سبيل المثال فإن السلوك العدو اني الذي يقوم به المر اهقين ضد المجتمع ليس نتيجة لتغير ات هرمونية في البلوغ ولكن نتيجة لعملية التنشئة الاجتماعية التي تبدأ بشكل مبكر جداً في الطفولة وتستمر حتى المر اهقة. كما أن النظرية ترى بأن سلوك المر اهقين بعتبر سلوكاً

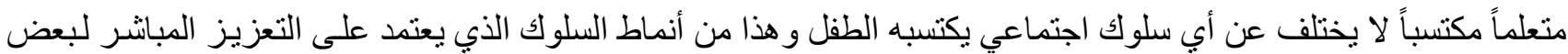
أعمال الأطفال التي يثابون عليها و أيضاً يعتمد على التقليد الاجتمـاعي لسلوك أثناص آخرين في نفس البيئة (بيومي،2002:

\section{3- - نظرية اللاتمركز (Ausubel).}

و هذه النظريـة مرتبطة بأوسوبيل الذي ركز على تطور الأنـا، والانطلاق من العوامل المتعددة التي تتحكم في تطور المر اهقة، ووفقاً لهذه النظرية تبدأ أول مرحلة من مر احل المر اهقة بالتمركز على الأسرة ابتداءً من الطفولة الأولى، من خلال البحث عن الأنا بمو افقة الو الدين، وعندما ينتقل من الطفولة إلى مرحلة الرشد، و الميل نحو اللاتمركز بالاعنمـاد على الذات، و الميل نحو الاستقلالية الثخصية، فينسلخ المراهق عن تمركز الأنـا، ويعني هذا ضـرورة الانتقال من التبعيـة إلى الاستقلالية، وبالتالي فتمة مجموعة من العو امل التي تتحكم في هذا التطور و التحول منها على سبيل المثال (عامل البلوغ، والعامل المعرفي،

$$
\text { و العامل الثقافي، والعامل الاجتماعي، و العامل النفسي). }
$$

\section{4- ن نظرية ألبورت (Alport).}

لم يهتم ألبورت بتطور الجانب الجنسي لدى الطفل و المر اهق كما فرويد، ولكن مـا يهمه هو تتبع تطور الذات أو الأنـا أو تطور الثخصية، بمعنى أن الأنا هي التي تساهم في تطوير الثخصية من الطفولة نحو المر اهقة، ولذلك فالفرد يهتم بذاته كثير اً حين وصـوله إلى فترة البلوغ و المر اهقة، في محاولة منـه لإثباتها أو تأكيدها أو الدفاع عن استقلاليتها بكافة السبل المتاحسة و الممكنة، وقد رصد ألبورت تطور الذات عبر المر احل المختلفة ابتداءً من مرحلة الطفولة حتى مرحلة المر اهقة والثباب، إذ فه يتحدث في البداية عن الذات الجسمية، فمرحلة هوية الذات، ثم مرحلة تأكيد الذات وتثبيتها، ثم مرحلة تعميق الذات وتوسيعها في المدى، ثم مرحلة صورة الذات، ثم مرحلة الذات العقلية أو الذات العارفة، ثم مرحلة المر اهقة الاستقلالية، كمـا أن دورة النمو في مرحلة المر اهقة تعبد هاجس الذات من جديد وتضعه في بؤرة الاهتمام أو الصدارة، و إذا كان العامل البيولوجي و العضوي هو الذي أيقظ لدى الطفل في شهوره الأولى الثُعور بالذات، فإن هذا العامل نفسه وبسبب مـا يضفيه من تغيرات مفاجئة على هـ الثخص في سن البلوغ يشكل من جديد عاملاً مهما في إثارة الاهتمام بالذات وتقصي جو انبها ومكوناتها، كمـا يضـاف إليـه نمو القوى و القدر ات العقلية لدى الفرد و التي أصبحت قادرة على ممارسـة أثند العمليـات العقلية قوة وتقيداً وتجريداً.( أوزي،

در اسة (المجالي، 2003) بعنوان " مرحلة المر اهقة ومشكلاتها في المجتمع الأردني: وخلصت نتائج الدراسـة إلى وجود مشكلات مختلفة في الثدة يعاني منها المر اهقين، حيث نبين أن المشكلات الصحية كانت نسبتها متدنية وقد كان من أبرز المشكلات الصحية التي يعاني منها المر اهقين حب الثباب، 
أما المشكلات الاقتصادية فقد كانت غير واضحة، حيث تبين أن أكثر أفراد العينية لا يعانون من مشكلات اقتصـادية على الرغم من أن معظم العينة هم من ذوي المستوى الاقتصادي المتوسط و المحدود وقد برجع ذلك إلى أن المر اهق يخجل من الحديث عن لهن مشكلاته الاقتصادية أمام الأخرين، أما فيما يتعلق بالعلاقات الاجتماعية فقد تبين أن النسبة الأكبر من أفراد العينة يملكون القدرة على إقامة علاقات ناجحة مع الناس، كما تبين عدم وجود مشكلات أسرية تتعلق بعلاقة المر اهقين مع أخوتهم في حين تبين أن معظم أفر اد العينة يعانون من مشكلات مع و الديهم. وقد أوصت الدراسة بضرورة تفعيل دور الاعلام من خلال نشر بر امج عن به مرحلة المر اهقة و التغير ات المر افقة لها لتثقيف الأهل وتو عيتهم بخصائص هذه المرحلة من حياة أبنائهم. در اسة (جلال، 2007) بعنوان " مشكلات المر اهقة الأكثر شيوعاً من وجهة نظر المعلمات "، وخلصت نتائج الدراسـة إلى أن أكثر المشكلات النفسية شيو عاً بين الطالبات في سلطنة عمان هي صعوبة التحكم في العو اطف، بينما الثـعور بالملل يعد من أبرز المشكلات لدى الطلبة في البحرين، كما اتضح أن المشكلات الاجتماعية والأسرية الأكثر شيو عاً بين الطالبات في كل من سلطنة عمان ومملكة البحرين كانت عدم القدرة على تنظيم أوقات الفر اغ، أمسا بالنسبة للمشكلات الاكاديمية الأكثر شيو عاً بين الطالبات في سلطنة عمان هي: الشعور بالضغط النفسي للوصول إلى مستوى تحصيلي متقدم يرضى الو الدين، بينمـا كانت أبرز هذه المشكلات الاكاديمية لدى الطالبات بمملكة البحرين هي شرود الذهن و السرحان أثنـاء الحصـة، كمـاتوصلت النتائج لعدم وجود فروق ذات دلاله إحصائية في كل أنو اع المشكلات والدرجة الكلية بين طالبـات المرحلـة الثانويـة في كل من سلطنة عمان ومملكة البحرين لصالح مملكة البحرين في كل الحالات . .

در اسة (فقيهي، 2007) بعنوان " المشكلات السلوكية للى المر اهقين المحرومين من الرعايـة الأسرية في المملكة

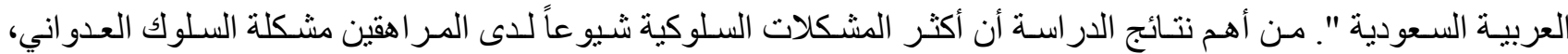
و المشكلات السـلوكية المتعلقة بالذات، و المشكلات السـوكية التعليميـة، المشكلات الأخلاقيـة، كذللك وجود فروق ذات دلالـه إحصائية لمتغير العمر في محور مشكلات السلوك العدواني، ومحور المشكلات السلوكية الدينية و الأخلاقية، أنما بقيـة المحاور فلم تكن هنالك فروق ذات دلاله إحصائية.

ودر اسة (البدري، 2008) بعنو ان " و اقع مشكلات المر اهقة لدى طلبة المرحلة الثانوية التخصصية بمدينـة طر ابلس " ، وكـان من أهم نتـائج الدر اسـة أن أبرز مشكلات المر اهقة التـي تو اجه طلبة وطالبـات المرحلـة الثانويـة التخصصية بمدينـة طر ابلس هي المشكلات النفسية ثم الدر اسية ثم الاجتماعية ثم مشكلات التكيف للمستقبل التربوي و المهني، كما توصلت الدر اسـة إلى أن أبرز مشكلات المر اهقة داخل كل محور من محاور المشكلات هي : فيما يتعلق بالمشكلات النفسية وجد أن مشكلات سر عة الغضب و الثعور بتأنيب الضمير هي أبرز المشكلات، وفيما يخص المشكلات الدر اسية فهي : طريقة شرح المعلمين و عدم مسـاعدتها على الفهم، و الثـعور بـأن النظم المدرسية متشـدة ــ وقد أوصت الدر اسـة بضرورة در اسـة الحاجـات النفسية

و الاجتماعية والدر اسية لدى المر اهقين ومدى ملائمة سوق العمل لها. در اسة (غالي، 2011) بعنوان " مشاكل الثباب المر اهق في المرحلة المنوسطة بالرياض "، حيث نوصلت النتائج أن

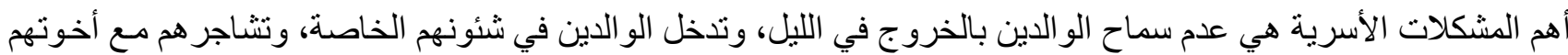
في المنزل كثثر اً، كما لا يمنحهم والديهم الحرية في شر اء احتياجاتهم بأنفسهم، وبالنسبة لأهم المشكلات الجنسية والجسمية فقد توصلت النتائج إلى أن الخجل من التحدث في أمور الزواج، وأن المدرسين لا يحدثونهم عن الأمور الجنسية، 
وأن المدرسة لا تهتم بالثقافة الجنسية، وقد أوصت الدراسة بضرورة توطيد الصلة بين المدرسـة والمنزل عن طريق تششيط فاعلية مجالس الآباء و المعلمين و إقامة المعارض و الندو ات و النشاطات التي يحضر ها الآباء ويكون هدفها زيادة التعاون بين المدرسة والآباء.

ودر اسـة (أبو منديل، 2016) بعنو ان " المشكلات السلوكية وعلاقتها بالتو اصل الأسري للدى المر اهقين مستخدمي الهو اتف الذكية من وجهة نظر الو الدين " وكـان من أهم نتائج الدراسـة أن بلـغ الوزن النسبي للمشكلات السلوكية للمر اهقين مستخدمي الهو اتف الذكيـة مـن وجهة نظر الو الدين (43.2\%)، أي بدرجـة متوسطة، وبلـغ الوزن النسبي للتو اصل الأسـري (52.5\%)، كمـا أظهرت الدر اسـة وجود علاقة عكسية ذات دلاله إحصـائية بين الدرجة الكلية للمشكلات السلوكية وأبعادهـا الثلاث (النفسية، الاجتماعية، الدر اسية) و التو اصل الأسري للمر اهقين مستخدمي الهو اتف الذكية من وجهة نظر الوالدين، وقد أوصت الدر اسـة بضرورة توظيف استخدام الهو اتف الذكية في تعديق التو اصل الأسرب، وتوجيه المر اهقين نحو الاستخدام الرشيد للهاتف الذكي، و انثاء مر اكز أسرية متخصصة لعلاج المشكلات الأسرية. در اسة (الهبيدة، 2016) بعنوان " مشكلات المر اهقة و علاقتها ببعض المتغير ات لدى عينة من طلبـة المرحلـة الثنانويـة في الكويت "أظهرت نتائج الدراسـة أن مجالات المشكلات التي يو اجها الطلبة المر اهقين من أبنـاء المطلقين في الكويت هي مجال المشكلات النفسية، ثم المشكلات الاجتماعية ثم المشكلات الاكاديمية، كمـا أظهرت النتائج وجود اختلاف في ترنيب مجالات المشكلات بين أفر اد عينة الطلبة المر اهقين لأسر كاملة لأبناء غير المطلقين وعينة الطلبة المر اهقين من أبناء المطلقين في الكويت على مجالات المشكلات، كما أظهرت النتائج وجود فروق جوهريـة بين منوسطات الدرجات في المجالات الثلاثة الاكاديمي و الاجتماعي و النفسي بين متوسطات أفر اد العينة لأبناء غير المطلقين وعينة الطلبة المر اهقين من أبناء المطلقين في الكويت تعزى للطلاق، ولصالح عينة الطلبة المر اهقين من أبناء المطلقين في الكويت. وقد أوصت الدراسـة بضرورة وضـع بر امج ارشادية للأبناء الذين يعانون من انفصال الو الدين من جهة وللحد من انتشار ظاهرة الطلاق من جهة أخرى.

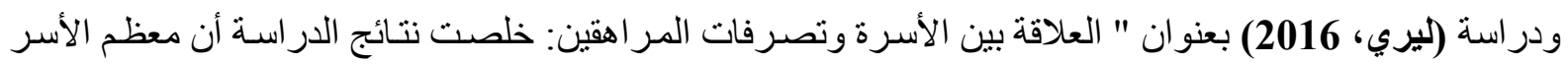
الكوينية تعامل المر اهق معاملة موضو عية وتتـجعه، ولا تتدخل كثير اً في شـئونه الخاصـة، و إنمـا تسـاعده على إيجـاد الحلول المناسبة للمعوقات و التحديات التي تعترض طريقه. وقد أوصت الدر اسـة بضرورة حل النز اعات الأسرية لانعكاسـاتها السلبية على المر اهق وضرورة اشر اكه في اتخاذ القرارات التي تهم الأسرة بوصف ذلك نوعاً من التدريب على تحمل المسئولية ممـا يحتم إثر اكه في اتخاذ القرار ات.

التعقيب على الار اسات السابقة. أولاً: أهم النقاط التي ركزت عليها الدراسات السابقة. 1- في ضوء نتائج الدراسات السابقة، يتضح للباحث مدى أهمية در اسة مرحلة المر اهقة ومشكلاتها لما لها من تأثير على حياة الاسرة واستقرار ها. 2- ركزت دراسة كلاً من (الهبيدة، 2016)، (غالي، الاسنرة 2011)، (البدري،2008)، (فقيهي، 2007)، (جلال، 2007)، (المجالي (2003)، (أبو منديل، 2016) على در اسـة المشكلات التـي تواجـه المر اهقين وطرق التعامل معها. بينمـا ركزت در اسـة (ليري، 2016) على طبيعة العلاقة بين الأسرة وتصرفات المر اهقين فيها. 
المجلة الدولية لنشر البحوث والدراسات

International Journal of Research and Studies Publishing
المجلد الثالث - الإصدار السادس والعشرون تأريخ الإصدار: 20 ديسمبر 2021م

ثانياً: أوجه اتفاق الاراسة الحالية مع الدراسات السابقة. 1- اتفقت الدراسة الحالية مع عدد من الدراسات السابقة مثل دراسـة (المجالي، 2003)، (فقيهي، 2007)، (البدري، 2008)، (أبو منديل، 2016)، (الهبيدة، 2016)، (ليري، 2016) على استخدام منهج المسح الاجتماعي كمنهج مناسب للار اسة. 2- اتفقت الدراسة الحالية مع در اسة كلاً من (جلال، 2007)، و (غالي، 2011) على استخدام المنهج الوصفي التحليلي كمنهج مناسب للار اسة. 3- تتفق الدر اسات السابقة مع الدر اسة الحالية في استخدام الاستبيان كأداة رئيسية لجمع البيانـات مثثل دراسـة كلاً من (جـلال، 2007)، و(غالي، 2011)، (البدري، 2008)، (أبو منديل، 2016)، (الهبيدة، 2016)، (ليري، 2016).

\section{ثالثاً: أوجه اختلاف الدراسة الحالية مع الدراسات السابقة.}

1- قدم الباحث عدداً من الدر اسات السابقة المحلية و العربية المختلفة التي تتفق مضموناً مع الدر اسة الحالية، ولكنها تختلف و لا تتفق مع الثق الثاني لعنوان الدراسة الحالية وهو الأثر المترتب على الاستقر ار الاسري من مشكلات مرحلة المر اهقة، كما اختلفت في مكان تطبيق الدراسة، حيث أن هناك اختلافاً في بيئات الدر اسة حيث طبقت في المملكة العربية السعودية در اسة كلاً من (غـالي، 2011)، و(فقيهي، 2007)، بينمـا در اسـة (جـلال، 2007) طبقت في سلطنة عمـان، ودر اسـة (البدري، 2008) طبقت في ليييـا، ودر اسـة كـلاً مسن (ليـري، 2016) و (الهبيـدة، 2016) طبقت في الكويت، ودر اسـة (المجالي، 2003) طبقت في الأردن، ودر اسة (أبو منديل، 2016) طبقت في فلسطين ـ اما الدر اسة الحالية طبقت على عينة من أباء و أمهات المر اهقين بمحافظة جده. 2- هناك اختلافاً في مجتمع البحث وحجم العينة، حيث طبقت در اسة كلاً من (المجالي، 2003)، (البدري ،2008)، و(غالي، 2011)، و(أبو منديل، 2016) على عينة من المر اهقين، اما الدر اسة الحالية طبقت على عينة من أباء وامهات لبعض المر اهقين.

المر اهقة هي مرحلة عمرية مهمة في حياة الإنسان، كما أنها فترة انتقالية يصاحبها عدة تغيرات في الجوانب المختلفة للثخصية الإنسـانية، وهـي وفق هـذا المنظـور مرحلـة بالغـة التعقيد وفترة عمريـة متوسطية بـين البسـاطة و الغمـوض بـين اللامسوؤلية والمسئولية، و هذا المرحلة لها تأثثير كبير على واقع الأسرة واستقرارها، ويستعرض الباحث في هذا المبحث أهم مفاهيم ومصطلحات مرحلة المر اهقة ومشاكلها وطرق التعامل معها، كذلك استعر اض مفهوم الاستقرار الأسري وأهميته وأهم مقو ماته، وكذلك المر اهقة و المناخ الاسري و أهم المشكلات الأسرية المصاحبة لمرحلة المر اهقة. 
المجلة الدولية لنشر البحوث والدراسات

International Journal of Research and Studies Publishing
المجلد الثالث - الإصدار السادس والعشرون

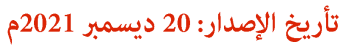

\section{أولاً: مرحلة المراهقة ومشكلاتها}

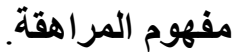

هنالك عدة تعريفات للمر اهقة كل منها يؤكد الأخر ونصنع في النهاية مفهوماً كلياً عن هذه المرحلة وفي مجملها فهي فترة من حياة كل فرد تبدأ بنهاية الطفولة وتتتهي بابتداء مرحلة النضـج أو الرشد وهي إمـا تكون فترة طويلة الأمد أو قصيرة.

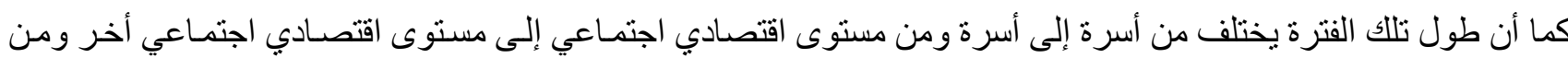
حضارة إلى حضارة (زهر ان، 287: 1971 (287). فالمر اهقة هي حالة من النمو تقع بين الطفولة وبين الرجولة أو الأنوثة، وإن فترة العمر لا يمكن تحديدها بدقة، لأنها تعتمد على السرعة الضرورية في النمو الجسمي، وهي متفاوتة، بينما عملية النمو السيكولوجي ليست غير محددة فحسب، و إنما هي غامضة أيضاً، ومن غير السهل أن تفرز هذه المرحلة من حياة الإنسان حتى يصبح الفرد نامياً بصورة كلية، وهذه الفترة من الناحية السيكولوجية تشمل أولئك الأفر اد الذين هم في العقد الثاني من الحياة " (الحافظ، 1990 :32.) و هي المرحلة التي تسبق وتصل بالفرد إلى اكتمـال النضـج، ويكون بذللك عمر الفرد 21 سنة ويمتد من البلوغ إلى :لى

كما نجد أن المر اهقة هي" تلك التغيرات أو التقلبـات الفيزيولوجيـة العنيفة التي تصـاحبها تغير ات ثانويـة تطر أ على مختلف أعضاء الجسم وتبدو للمر اهق في أول الأمر اضطر ابا جسمياً وخلاًا عضوياً يزيد من حساسيته لنفسه " (المليجي، 1997 :320). ويستخلص الباحث من المفاهيم السـابقة أن المر اهقة مرحلة فاصلة بين الطفولة و الرشد وتتميز بكونها تحدث فيها تغير ات تمس الفرد في جميع النواحي: الفيزيولوجية و النفسية والعقلية والاجتماعية والتربوية و التعليمية، كما أنها تعد من أخطر المر احل التي يمر بها الإنسان في نموه حيث يتحول فيها من شخص غير مكتمل عاجز إلى شخص نامي يعتمد على نفسه.

\section{أهمية دراسة مرحلة المر اهقة.}

تعد در اسـة مرحلة المر اهقة في غايـة الأهمية، حيث أنها تضـع الفرد على أبواب مرحلة جديدة من حياتهه وهي مرحلة الثباب، ولذلك نجد في جميع أنحاء العالم أن المنظمات التربوية قد أولتها اهنماماً بالغًا لعدة أسباب يوضحها ضـميرية (2009: 32) فيما يلي:

1- المعرفـة الكاملـة بتكوين المر اهق نفسياً واجتماعيـاً وجسمياً وعقلياً، لأن هذا يؤثر في اختيـار المنهج والوسـائل الملائمـة للتربية و العو امل المؤثرة فيها.

2- معرفة سمات وخصائص هذه المرحلة و التغيرات التي تطر أ على الفرد فيها، فلابد من مواجهة مرحلة المر اهقة باعتبار هـا مرحلة انتقال وتغيير كلي باستخدام كل ما يضمن سلامتها من الوقوع في الفساد و الانحر اف. 3- يتعرض المر اهق لمشكلات نفسية واجتماعية وخلقية ودينية تحتاج إلى حلول علمية صحيحة تتفق مع نفسيته وتكوينه في هذه المرحلة، ولن تكون هذه الحلول ناجحة إلا إذا تفهمنا المر اهق ومشكلاته تفهماً صحيحاً. 
مظاهر النمو في مرحلة المراهقة. وتتمثل أهم مظاهر النمو في مرحلة المر اهقة كما يلي:

يعد النمو الجسمي من أهم التغيرات التي تطر أ على المر اهق، فهذا النمو لا تتناسب مـع سـر عة نموه العقلي و الانفعـالي و الاجتماعي في هذه المرحلة، كما أنها ليست مهمة في ذاتها بقدر ماهي مهمة من حيث التأثير المباشر على شخصية المر اهق و على سلوكه وقدرنه، بالإضـافة إلى تأثر كل واحد من جسم المر اهق و عقله وعو اطفه بـالأخر ، ويشتمل النمو الجسمي على مظهرين هما: (قاسم، 2004 : 2004 (149). • النمو الفيزيولوجي: و المقصـود بـه التغيرات التي تحدث في الأجهزة الداخلية للإنسـان، مثل تغيرات إفرازات الغدد الصماء و الغدد الجنسية، وتغير ات النضج الجنسي و البلوغ، و التي تعني وصول الأعضاء التناسلية للنضج الوظيفي الذي يمنح الفرد القدر على أن يصبح لديه القدرة على التناسل. ونيل • النمو العضوي: و المقصود به نمو الأبعاد الخارجية للمر اهق، كالطول و الوزن و التغير في ملامـح الوجهـ و غير هـا من المظاهر الجديدة المصاحبة لعملية النمو التي سيكون لها أثزها ونتائجها، كما يجب عل المر اهق أن يتقبلها ويكيف حياته وسلوكه وفقاً لمتطلباتها.

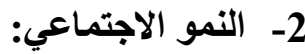
من الملاحظ أن هنـاك اتسـاع لنطاق الاتصـال الجماعي ونز ايد لمشـاركته للآخرين في الخبرات و المشـاعر و الاتجاهـات و الأفكار نتيجة للتغير ات الجسمية والعقلية والانفعالية التي تحدث للمر اهق، وكذلك تستمر عملية التنشئة الاجتماعية من الأشخاص المهمين في حياته كالأسرة متمثلة في الو الدين و المقربين من الرفاق. (ملحم، 365: 2004 :

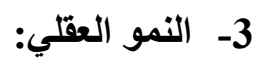

و أهم ما يميز مرحلة المر اهقة هو نمو ونضج القدرات العقلية، ففي تلك المرحلة ينمو الذكاء العام ويسمى القدرة العقلية التامة، وكذلك تتضح الاستعدادات و القدر ات الخاصة وتزداد قدرة المر اهق على القيام بكثير من العمليات العقلية العليا كالتفكير و التذكير و التخيل، حيث تتحول الحياة العقلية من البسيط إلى المعقد، أي من الإدر الك الحركي إلى إدراك العلاقات المعقدة (ملحم، 366: 2004 (م) 4- - 4 - النمو الانفعالي: لقد أكدت العديد من الدر اسات التي قام بها البـاحثين على وجود ارتباط وثيق ببين الانفعالات التي تحدث للمر اهق بعالمـة الخارجي المحبط به عبر مثير اتها واستجاباتها، وبين العالم العضوي الداخلي عبر شـعور ها الوجداني وتغير اتها الفيزيولوجيـة الكيميائية، كمـا يخضـع ارتباطها الخـارجي خضوعاً مباثـراً لنمو الفرد، بينما نظل مظاهر هـا الداخلية أقرب إلى الثبات و الاستقرار منها إلى التغيير التطور. 
أنواع و أشنكال المراهقة.

ففي المجتمعات البدائية يكون الانتقال مباشـر اً من مرحلة الطفولة إلى الرجولة، أمـا في المجتمعات المتحضرة فتتم بأثكال مختلفة حسب الظروف الاجتماعبة و الثقافية التي يعيش في وسطها المر اهق، وقد أسفرت الدر اسـات على هناك أثكالاً مختلفة للمر اهق منها: (أبو منديل، 1- ـر اهقة سوية خالية من المشكلات و الصعوبات، يكون فيها المر اهت مدركاً لذاته متحملاً لمسئولياته، ومن أهم مـا يميزهـا الهدوء و الاتزان الانفعالي و العلاقة الجيدة مع الآخرين، و عدم الإسر اف في التخيل أو أحلام اليقظة.

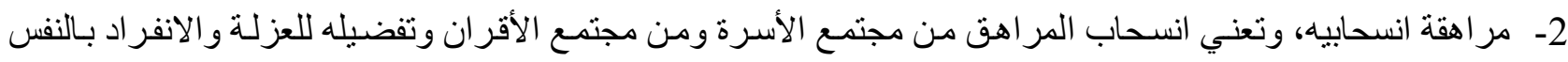
منتأمًا لذاته و مشكلاته. 3- مر اهقة عدو انية، ويكون السلوك العدو اني للمر اهق على نفسه و على غيره من الناس هو السمة الغالبة عليه. 4- المر اهقة المنحرفة، ويقصد بها انحر اف المر اهق عن أنماط السلوك السوي و المبل للانحر اف الخلقي و الجريمـة مثل السرقة و الادمان.

مشكلات مرحلة المراهقة. لا يعني البحث عن مشكلات مرحلة المر اهقة أن مشكلات هذه المرحلة تفوق مشكلات المر احل الأخرى، فلكل مرحلة لها عملياتها الانتقالية التي يفرضهـا المجتمع، كمـا أن لكل مرحلة حاجاتها الفسيولوجية و النفسية و الاجتماعيـة، والتي تتطلب جميعها الإشباع، كما سيحدث توتر واختلال و عدم التكيف مع البيئة المحيطة إذا لم يتوفر للفرد ذلك الاشباع، كما أن تكيف المر اهق لا يعني خلوه من المشكلات، بل يقاس تكيف الفرد بقدرته على مو اجهة المشكلات و إيجاد حلول لها، و عندما يتوفر

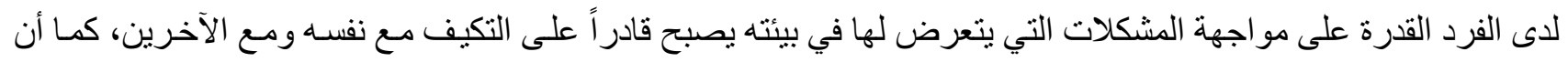
الهدف الأساسي لعرض مشكلات المر اهقة هو مساعدة المر اهق في فهم نفسـه ومشكلاته، و اكتسابه الأسـاليب السوية لمواجهة

هذه المشكلات و إيجاد الحلول المناسبة لها. ويعرف الزر اد (72:1997) مشكلات المر اهقين بأنها " عبارة عن عقبة أو عائق تحول بين الأفر اد وبين إرضـاء حاجاتهم". وبتحديد المشكلات التي تواجه المر اهقين سنجد أنها وجدت نتيجة للتفاعل السلبي بين ثلاثة أبعاد يمكن عرضـها على النحو التالي: • البعد الأول: مجموع الحاجات التي تستند إلى مكونـات الثخصية، مثل الحاجـات (البيولوجية و السبكولوجية والاقتصادية و الثقافية) للفرد المر اهق. • البعد الثاني: السياق الاجتماعي و الثقافي الذي يمتلك إمكانيات إثباع الحاجات الأساسية للمر اهقين.

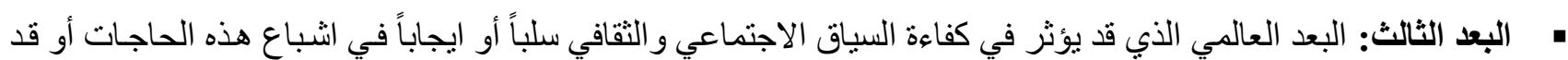
يزود الثخصية بحاجات جديدة. كما تلعب هذه الأبعاد الثثلاثة السابقة دور اً أساسياً في تكوين شخصية المر اهق بما تحمله في طياتها من صفات واستعدادات موروثة وتفاعل اجتماعي وثقافي معين واتجاهه النفسي وهي تحدد نوع وكم المشاكل التي تو اجهه. 
وفي هذا السياق تتضح مشكلات المر اهقين من خلال ما يلي: (البدري، 45: 2008 : 1- قـد ترجع مشكلات المر اهقين إلى المشكلات التي يعاني منها أبناء المجتمع، ومن ثم فإن معالجة هذه المشكلات يستوجب

التعامل المباشر مع جذور ها في بناء المجتمع ومو اجهتها عامة وشاملة. 2- قد تنقسم مشكلات المر اهقين إلى أنماط من المشكلات هي: - - المشكلات التي يعاني منها المر اهقين بصفة عامة. - ما قد تعاني منه القطاعات المنحرفة من المر اهقين من مشكلات ذات الصبغة الإنحر افية. 3- أن المشكلة تمر بمرحلتين هما:

- المرحلة الأولى: وتكون فيها المشكلة مجرد مشكلة اجتماعية، لذللك يمكن مواجتها عن طريق بعض التغييرات في البيئة المباشرة للمشكلة.

- المرحلة الثانية: وفيها تصبح مشكلة المر اهق مشكلة بنائية حيث ينطلب حلها اجر اء تغيير ات جذريـة في البناء القائم للمجنمع.

4- إن محدودية المشكلة و انحصار ها في بعض قطاعات المر اهقين، سيجعلها تظل في حدود كونها مشكلة اجتماعية، أمسا إذا اتسع نطاقها بحيث هددت بالانتشار بين مختلف القطاعات لما قاربت من التحول إلى مشكلة بنائية يتطلب مو اجهتها حلو لاً

$$
\text { جذرية. }
$$

كما يمكن استخلاص أهم هذه المشكلات من خلال الدر اسات و البحوث التي تم أجر اهها لدر اسة مرحلة المر اهقة وأهم

$$
\text { مشكلاتها فيما يلي: }
$$

\section{1- المشكلات الصحية والجسمية.}

تشير الدر اسات إلى أن المشكلات الصحية والجسمية تمثل محوراً هامـاً من المشكلات التي يتعرض لها المر اهق، ونعني بها هنا تللك المشكلات المتعلقة بالحالة الصحية للمر اهق و الاضطر ابات التي يتعرض لها ومدى تقبله للتغيرات الجسدية التي هي تحدث له في هذه المرحلة (عطا، 1997).

2- المشكلات النفسية.

و هي نتاج عو امل كثيرة بعضها اجتماعي يعود لظروف بيئية محليه، وبعضها فسيولوجي كالنمو الجنسي السريع الذي يثير اهتمام المر اهق على إثباع حاجاته المختلفة، و الدافع الجنسي وما يصاحبه من محاو لات لإشباعه و التي تنعكس بشكل أو بـآخر على مشاكله النفسية (ز هران، 1995).

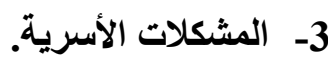

تعبر المشكلات الأسرية عن نمط العلاقات الأسرية السائد والاتجاهات الو الدية في معاملة أو لادهم المر اهقين، ومدى تفهم الآباء لحاجاتهم، ونظرة المر اهقين إلى هذه المتطلبات الأبوية، كما تعبر عن رغبة المر اهق في الاستقلالية و الاعتماد على الذات في مو اجهة متطلبات الحياة، فالمر اهق يود الاعتماد على نفسه في تتظيم وقتهـ وانجاز قرار اتهـ بنفسـه عن طريق التخلص من مر اقبة الو الدين له (زهران، 1995). 
المجلة الدولية لنشر البحوث والدراسات

International Journal of Research and Studies Publishing
المجلد الثالث - الإصدار السادس والعشرون تأريخ الإصدار: 20 ديسمبر 2021م

4- - المشكلات المدرسية.

وتعني المشكلات التي تتعلق بعلاقة الطالب بمدرسيه وزملائه ومدى تكيفه معهم، كما تشير أيضًا إلى المشكلات المرتبطة بعملية التحصيل الدر اسي وطرق الاستذكار والامتحانات المدرسية، حيث يفرض الجو المدرسي على المر اهق أن يتعامل مـع المدرسين و المنهج و الو اجبات و المدرسة وأنظمتها والتي من شأنها جميعًا أن تحد من حريـة المر اهق وتقلل من قيمته، وبالتـالي يتمرد المر اهق ويفتل في إقامة علاقات منوازنة داخل مدرسته (الأشول، 1998).

5- 20 - المشكلات المهنية.

تعد مرحلة المر اهقة من أخطر المر احل الحياتبة للفرد، حيث أنها ترتبط بمستقبل المر اهق وحاجاته الملحة في المسـاعدة للتخطيط لمستقبله الحياتي وجهله بالقدرة العملية التي توفر له فرصة تعليم مهنة أفضل (عطا، 1997).

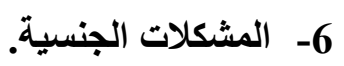
في هذه المرحلة يعاني المر اهق من عدم معرفته لحقيقة الجنس وطبيعة مشكلاته، فيلجأ إلى أقر انه في كثير من الحالات

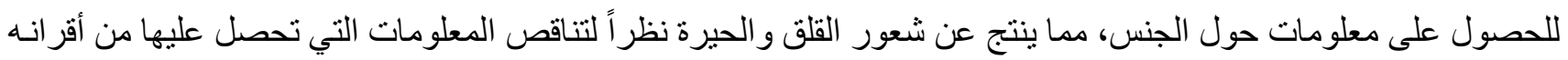
(عطا،1997)

\section{7- المشكلات الأخلاقية.}

لا شك أن هناك أهمية كبيرة للدين و الأخلاق في حياة المر اهق، حيث يظهر الثعور الديني بوضوح في هذا المرحلة، كما

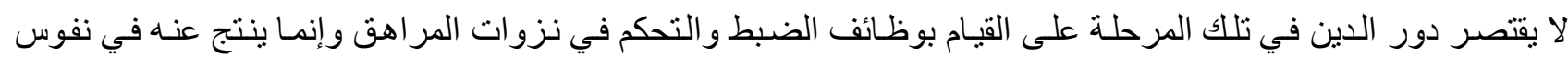
المر اهقين حاجات نفسية أكثر عمقاً (ملحم، 2004).

8- المشكلات الاقتصادية.

من المؤكد أن المشكلات الاقتصـادية تلعب دوراً هاماً في حياة المر اهق وتسبب لـه الكثير من القلق كمـا تعد المشكلات الاقتصادية مؤشرًا على ضعف المستوى الاقتصادي، مما سترتب عليه عدم إنشباع لحاجـات ومطالب المر اهق، وفي الغالب تدور المشكلات الاقتصادية حول كيفية إنفاق المر اهق لنقوده و عدم استغلالها على الطريقة المنلى (الطواب، 1998). 9- - 9 - المشكلات الاجتماعية. كما تشبر المشكلات الاجتماعبة للمر اهق إلى فثلـه في العلاقات الاجتماعية ومدى تحقيق حاجاتـه إلى الاعتبار و القبول الاجتماعي و الانتماء و التقدير و عدم تكيفه مع الآخرين (عطا، 1997). طرق التعرف على مشكلات المراهقين: هناك بعض الطرق للتعرف على مشكلات المر اهقين بصورة صحيحة وموضوعية ومن هذه الطرق: 1- - طريقة الملاحظة المباشرة: و المقصود بها هو ملاحظة مظاهر سلوك المر اهقين كأفر اد وجماعات بطريقة مباشرة، وذلك للتعرف على مشكلاتهم وفهم

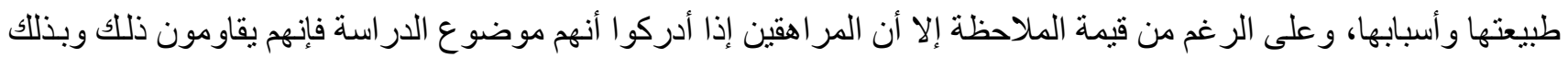

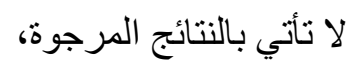


المجلة الدولية لنشر البحوث والدراسات

International Journal of Research and Studies Publishing
ملزجلد الثالث - الإصدار السادس والعشرون تأريخ الإصدار: 20 ديسمبر 2021م

كمـا أنـه قد تكون الملاحظة مقصودة ومخطط لهاوتتم من قبل الاختصاصسي المدرب، وربمـا تكون عرضية دون تخطبط ومزودة بوسائل علمية تساعد على تصوير سلوك الأفر اد (توفيق، 94: 94).

2- 2 - طريقة المقابلة الثخصية:

وتتم مع المر اهقين أنفسهم في محاولة لمناقتنهم حول المشاكل التي يشعرون بها، كما يتوقف نجاح هذه المقابلة الثخصية على مدى مهارة الثخص القائم بالمقابلة و على مدى استجابتهم له، كما يجب الإعداد الجيد للمقابلة والتخطبط لها من قبل القائم عليها، و أن يتمتع بمهار ات وصفات شخصية تساعده على إنجاح هذه المقابلة، مع مر اعاة توفر بعض الثروط لإنجاح المقابلـة

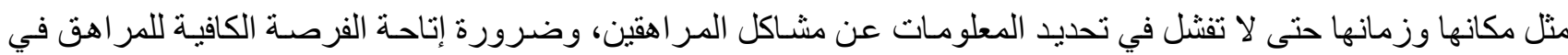
التعبير عن مشاكله بحرية دون تحفظ أو إلحاح ( الثيباني، 1997 :169). 3- طريقة الفحوص والتحاليل الطبية:

تكثف الفحوص الطبية عن المشكلات الصحية التي يعاني منها الفرد، ومدى تأثنير هذه المشكلات على حياته و على مستوى تو افقه، كما يمكن إضافة اختبار ات الميول و الاتجاهات واختبار ات عقلية ونفسية واختبار ات الشخصية بصفة عامة 4- طريقة التجربة المنظمة وطريقة دراسة الحالة: تحتـاج هذه الطريقة إلى إلمـام كاف بطرق البحث العلمي وبالمنـاهج وطرق القياس، كما يمكن أن يستخدم الباحث هذه الطريقة المفيدة في التعرف على مشاكل المر اهقين ودر اسة خصائصهم وحاجاتهم. 5- 5 مراجعة وتحليل الثقافة القائمة: و المقصود بها ثقافة المجتمع التي يعيش فيها الفرد، وتحديد ما تحتاجه الحياة الناجحة من الفرد الصالح في ذلك المجتمع من معارف ومهار ات و اتجاهـات، بالإضـافة إلى تحديد حاجـات المجتمع ومتطلبـات نموه وتقدمهـ لأنـه أذا عرفت مـا تتطلبه الحياة الاجتماعية الناجحة فسنتمكن من معرفة جانباً كبيراً من حاجات ومشكلات المر اهقين. 6- مراجعة وتحليل الدراسات التي أجريت في البلان الأخرى: و المقصود بها الدر اسات التي أجريت على حاجات و اتجاهات ومشكلات المر اهقين في تلك البلدان فمن الممكن أن نستفيد منها في تحديد حاجات المر اهقين ومشكلاتهم.

ثانياً: الاستقرار الأسري وأهم مقوماته

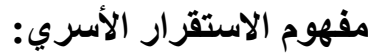

الاستقرار الأسري هو بناء علاقة زوجية تقوم على التوازن و التكامل بين الرجل والمر أة، ومن بظفر بهذا النوع من العلاقـة يستطيع بنـاء حياة زوجيـة على أسـاس من الاستقر ار، هذا التكامل المبنـي على الاحتر ام المتبـادل، و النـابع من سمو العو اطف و ارتقاء الفهم سيوجد شخصية اجتماعية تحمل صفات الطرفين بكل خصوصيتهما دون إلغـاء أبي منهمـا بل العكس بسنطيع كل من الزوجين أن يجد خصوصيته إلى جانب خصوصية الآخر في بونقة واحدة، ونسيج واحد يحمل عو امل تفتح

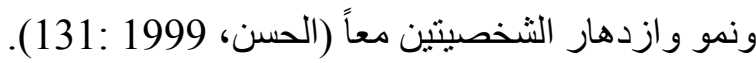


المجلة الدولية لنشر البحوث والدراسات

International Journal of Research and Studies Publishing
المجلد الثالث - الإصدار السادس والعشرون تأريخ الإصدار: 20 ديسمبر 2021م

ISSN: 2709-7064

ويعرف الاستقرار الأسري بأنه " العلاقة الزوجية السليمة التي تحظى بقدر عال من الخطيط الواعي الذي تر اعى فيه

الفردية و التكامل في أداء الأدوار لتحديد كيفية تحمل المسئوليات و الواجبات ومدى القدرة على مو اجنها مـع اعتبار ديمقر اطيـة

التعامل في الاسرة كي تسنطيع الصمود أمام الازمات وتحقيق المرونة والتكيف مع المتغيرات " (أبو سكينة، 1992: 36).

أهمية الاستقرار الأسري:

يشير أداء الأسرة لوظائفها و أدو ارهـا المتعددة إلى استقر ارها وتكيفها السليم مـع البيئة المجتمعية المحيطة، وتعتبر

قضية مرتبطة، فالتكيف الاجتماعي والصحي لأفراد الأسرة هما الأسـاس في عملية الاستقرار، كما يعد من المهم جدًا وجود

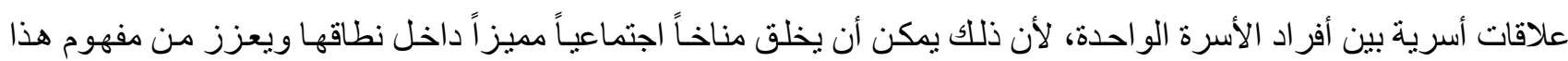
الاستقرار ، أما إذا حدث أي تغير داخل محيط الأسرة، فسوف تتأثر بشكل مباثر صحة الأسرة وأداؤهـا لوظائفها الاجتماعية على أكمل وجه، فحدوث أي تغيير يخلق نوعاً من عدم الاستقرار، فالاستقرار يعني الثبات في حين عدم هذا الاستقرار يعني التغير و الحركة، و الحركة في الغالب تخلق بعض المشكلات و الصر اعات و التناقضـات التي تحدث كنتيجة طبيعية لهذا التغيير

(الكندري، 2008 (93: (200)

خصائص الاستقرار الأسري:

ويعد من أهم خصائص الاستقرار الأسري ما ذكرته سميحة توفيق (1996) فيما يلي: 1- درجة المرونة التي تكتسبها الأسرة والتي تسمح لها بالتكيف مع المتغير ات التي قد تحدث في المجتمع الخـارجي ويكون لها تأثثر على الأسرة باعتبار ها جزء من مجتمعها الذي تعيش فيه. 2- وجود الفردية و التكامل في أداء الأدو ار لتحديد كيفية تحمل المسئوليات و الو اجبات ومدى القدرة على مو اجنتها مع اعتبار ديمقر اطية التعامل مع الأسرة كي تستطيع الصمود أمام الأزمات وتحقيق المرونة و التكيف مع المتغيرات.

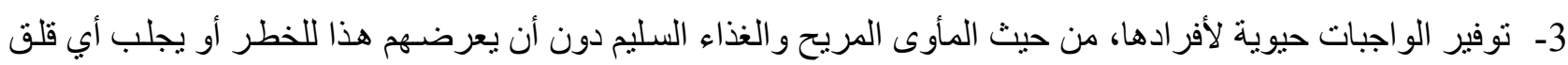

لهم.

4- - مساعد الأسرة لأطفالها كي ينمو ا نمو اً صحياً، مع غرس قيم الحب و الخير و الكر امة الاجتماعية في نفوسهر. 5- تدريب الأبناء على فن الحياة الاجتماعية في نطاقها الضيق، عندما تكون العلاقات الاجتماعية الإنسانية ماز الت بسيطة. 6- تتشئة الأطفال و إكسابهم السلوك و المهار ات و القدرات اللازمة و الخبرات كي يستطيعو ا مو اجهة قو انين السلوك العامة في المجتمع في المستقبل، بالإضافة إلى أن تكون استجابتهم للمو اقف الإنسانية المتعددة استجابة سليمة.

مقومات الاستقرار الأسري: يثير كريمة (2020: 467) إلى أن مقومات الاستقر ار الأسري كما يلي:

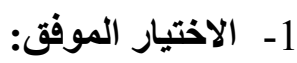
إن اختيار الفرد للشريك المناسب بعد أحد أصعب القرار ات التي تمكن الانسـان أن يتخذها طو ال حياته، فمن شروط

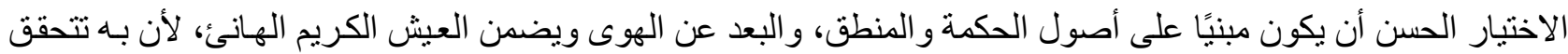
السعادة الزوجية التي تدعم تماسك واستقرار الأسرة، 
حيث يتخطى أثر ذلك إلى المجتمع ككل و لا يقتصر على الزوجين و أطفالهما فحسب، فالأسرة هي اللبنـة الأساسية في تكوين المجتمع، فإذا صلحت الأسرة صلح المجتمع كله و العكس صحيح، لذلك وجب على كل مقبل على الزو اج أن يتروى ويتمهل قبل اتخاذ هذا القرار المصيري لحياته المستقبلية.

2- الالتزام:

فالأسرة المستقرة يكون أفر اد ملتزمين بأداء الواجبات الموكلة إليهم، كما يعرفون جيداً مـا لهم من حقوق ومـا عليهم من واجبات، بالإضافة إلى الإخلاص والتضحية من أجل العائلة، وينبع هذا الالتز ام من نفوس أفر اد الأسرة دون تبعيـة أو اجبار عليه، فالجميع يحظى بالحرية و الاستقلالية التي تشعر هم بقيمة وجودهم و أهميتهم داخل أسرتهم المستقرة. 3- قضاء أوقات ممتعة: يعد من الأمور المهمة لدعم استقرار الأسرة وتعزيز التماسك و التآلف بين أفر ادها، هو أن بروح الفرد عن نفسه سو اء من

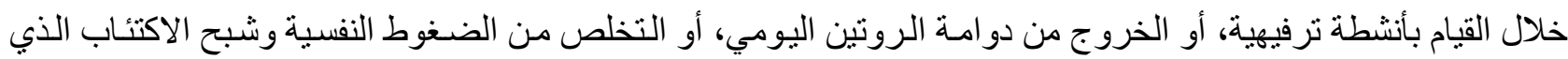

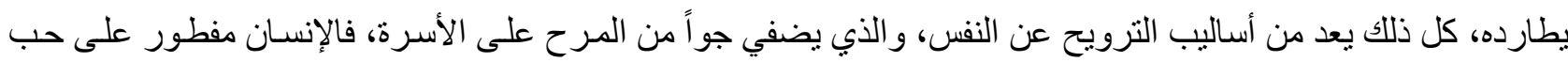

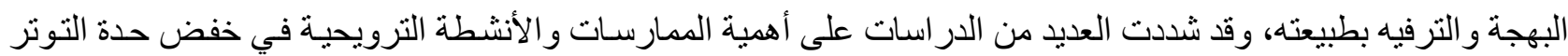
وتقليل الخلافات التي قد تنشأ بين الزوجين. 4- - تحمل الصعاب والحصول على الاعم:

حيث يكون هناك استعداد لكل من الزوجين ببذل الجهد الكافي للخروج من الأزمات وتخطي المشاكل التي تواجه حياتههـا الزوجية إذا ما مر أحدهما بظروف عصيبة كالمرض، وهذا ما تتميز به الأسرة المستقرة عن غير ها من الأسر، كما لا تقتصر

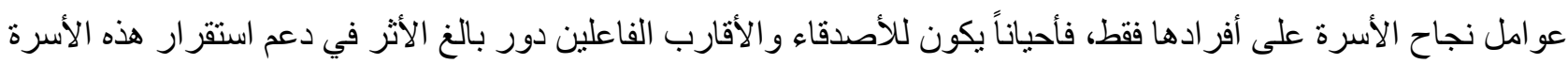
(صحاف، 2014: 61).

عوامل تحقيق الاستقرار الأسري: يثير الرفاعي (2017: 5-7) إلى أنه لابد من در اسة مجموعة من العوامل لتحقيق الاستقر ار في الأسرة من أهمها:

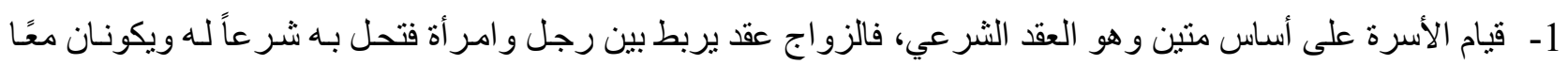

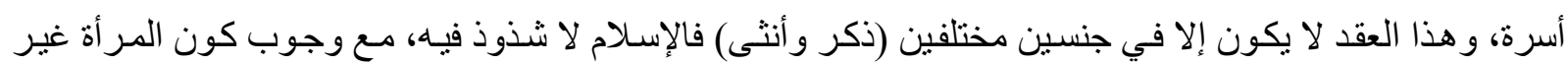
محرمة على الرجل حتى يصح العقد، وهذا العقد كغيره من العقود لابد من أن نتوفر فيه مجمو عة من الأركان الثروط؛ ليكون منعقداً بصورة صحيحة. 2- يجب أن تتوفر الثروط الخاصة بعقد الزواج و اللازمة لصحة الأركان ومنها: الإشهاد على العقد والتوثيق، فقد قال عليه الصلاة و السلام (لا نكاح إلا بولي وشاهدي عدل)، لذا فالإشهاد شرط لصحة عقد الزواج. 3- معرفة مـا يترتب على عقد الزواج من آثار (الحقوق الزوجية)، و الحرص على مر اعاتها سو اء أكانت هذه الحقوق مشتركة بين الزوجين كحسن المعاشرة، وحل الاستمناع، وحرمة المصاهرة، وثبوت النسب، و التعاون على طاعة الله، و التوارث، أو كانت خاصة بحق الزوج على زوجته كالطاعة، والمصاحبة، وصيانة عرضه،، وماله، 
و القيام على أمر البيت و عدم الخروج من بيته إلا بإذنه إلا لضرورة، أو كانت حقوقاً خاصـة بحق الزوجة على زوجها كحقها في المهر و النفقة والعدل، و المعاملة بالمعروف. 4- أن تقوم الأسرة على أساس التقوى وحسن العشرة، و انضباط أفر اد الأسرة بأحكام الشرع، فعلى الزوجين أن بتعاملا بالفضل و الإحسان قو لاً وفعلاً وخُلقا، لأن هذا يعد من أهم عو امل تحقيق الاستقرار للأسرة.

ثُالثاً: مشكلات المراهقة وعلاقتها باستقرار الأسرة. المناخ الأسري وعلاقته بالمر اهقين: لاشـك أن للعلاقـات الأسـرية التي تسود بـين أفر اد الأسـرة دوراً هامـاً في تتميـة شخصية المـر اهقين فيها، وأن الجو الديمقر اطي في الأسرة يكفل لهم الأمن وضمان الاستقر ار و الثعور بالانتماء للأسرة وبكيانها العضوي، أما إذا شاع في الأسرة العنف و إثـاعة الخوف فإن ذلك في الغالب قد يتيح للأبناء فرصة التمرد و الثورة و العنف أيضـاً، وتثنير الدر اسـات و البحوث أنـه من أسباب العنف لدى الأبناء في مرحلة المر اهقة العنف الأسري و المشاكل الأسرية، وأنه يجب أن يتفهم الو الدان أن سلطنهما ليست سلطة القمع و الكبت بل سلطة التوجيه و المشورة، وأنه يجب أن يعمل الو الدين على اتاحة الفرصـة للأبنـاء للمشـاركة في تحمل بعض المسئوليات الأسرية و أن يتاح لهم مسـاحة من المناقثـة و الاقتـاع و الثقة و ألا يكون الو الدين مر اقبان لكل تحركات الأبناء وسكناتهم . كما أن للأسرة تأثثر و اضح على سلوك المر اهق، حيث يرى فوتيل بأن هناك مقولة تؤكد على " إذا لم تحساول وضع نفسك مكان الطفل المر اهق، فلن نستطيع التو اصل معه" (فونتيل، 2001 :5). وتعد الأسرة أهم محيط للمر اهق باعتبار ها المؤسسـة والخلية الأولى و الأساسية في المجتمع التي ينشـأ بها المر اهق، وتلعب دور اً هاماً في مساعدته على تجاوز هذه الفترة بنجاح، ومن أهم المشـاكل التي يتعرض لها المر اهق في حياته اليوميـة، و التي تقف عائقاً أمام تحقيق التكيف النفسي و الاجتماعي هي علاقته بالر اشدين خاصة مع الآباء، حيث تلعب الأسرة دور اً هامـاً في نمو أفر ادها نمواً سليماً، ومن أهم وظائف الأسرة المحافظة على البناء الأسري و اشباع الحاجات الأساسية للأبناء. أهم مشكلات مرحلة المراهقة وتأُثير ها على الاستقرار الأسري. تشير العتوم (2019) الى أهم مشكلات الأسرة في مرحلة المر اهقة كما يلي: 1- الخوف الزائد على الأبناء: حيث يصبح الو الدين أثند خوفاً في هذه المرحلة، وأكثر حماينةً لهم، خصوصـاً أن الدُر اهقين يتعرضون للعديد من التّجـارب، ويقعوُن في المشـاكِل بصورةٍ مُستمرة، من هُنـا يُصبح خوف الو الدين أكبر، مدّا يُشكل مُشكلة حقيقية على صعيدٍ العلاقة التي تجمَع بين الو الدين و الأبناء المُر اهقين.

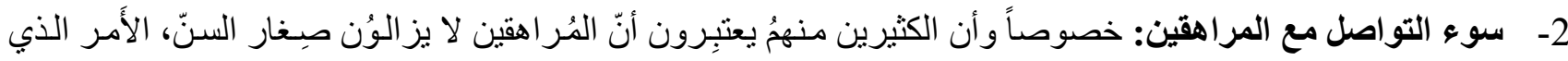

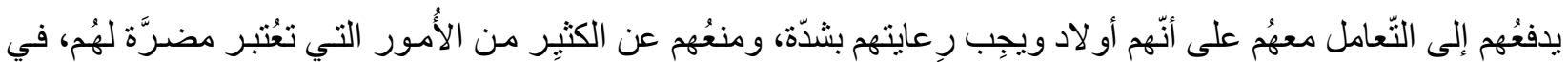
هذا الإطار يغيبُ الجِوار بينهم مدّا يؤُدّي إلى مشاكِل كَبيرة في استقر ار الأسرة. 3- الحرية الكاملة للأبناء: يسعى المُر اهق في هذه المرحلة إلى الحُصولِ على الحريّة الكامِلة للقِيام بكل ما يريد، لكن الو الدين يمنتِعون في كثيرٍ من الأحيان عن منح أبنائهم المُر اهقين هذه الحريّة، 
المجلة الدولية لنشر البحوث والدراسات

International Journal of Research and Studies Publishing
المجلد الثالث - الإصدار السادس والعشرون تأريخ الإصدار: 20 ديسمبر 2021م

خُصوصاً حرية التنقّل و السّهر و الخُروج برفقةٍ الأصدقاء، هذه الأمور تُعتبر بالنّسبة إلى الو الدين من الممنُوعات بشكلٍ

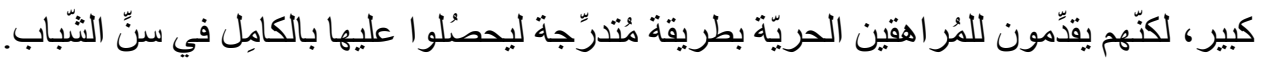

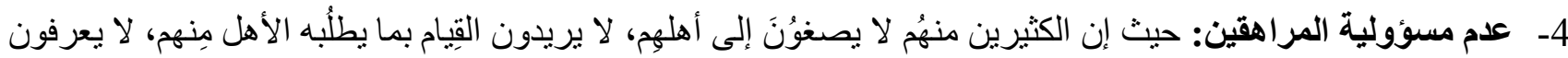

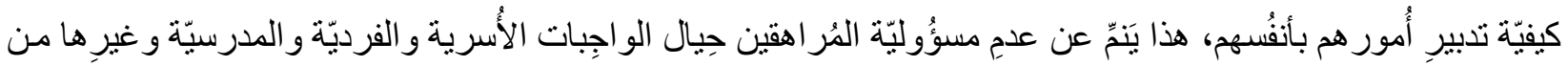
الأُمور التي يجِب أن ينتبَّهو إِلينها.

\section{الأخطاء التي يرتكبها المراهق بحق أسرته.}

هناك عدد من الأخطاء يرتكبها المر اهق بحق أسرته يثنير اليها البدري (2008) كما يلي:

$$
\text { 1- الابتعاد عن العائلة و عدم الرغبة في قضاء الوقت معهم. }
$$

2- عصيان الأوامر و عدم اتباع التعليمات، حيث يعتقِد الكثِِر مِن الأَناء أن عِصيان الأوامِر، يدُل على قوّة الشخصية.

$$
\text { 3- عدم العودة للمنزل في الوقت المحدد. }
$$

4- التذهُر أو الثكوى عند القيام بالو اجبات المنزلية. 5- عدم الاعنذار عند ارتكاب الأخطاء، و هذه الاشياء تجعل الآباء والأمهات يشعرُون بالاستياء. 6- مناداتهم بلا ألقاب أو بطريقة غير لائقة.

$$
\text { 7- - الامتتاع عن شكر هم. }
$$

8- السخرية من الأهل، حيث يسخرُ عدد كبير من الأبَناء من آبائهم و أُمهاتهم، ربما لطريقةِ تفكير هِمِ القديمة أو لِعدم مُو اكبتهم

$$
\text { لتطوّر ات العصر وما إلى ذِلِك. }
$$

\section{وظائف وأدوار الأسرة تجاه المراهقين.}

تتعدد وظائف الأسرة تجاه الأبناء المر اهقين، ويشير عفيفي (2002 :105) إلى أهم تلك الوظائف وتتمثل فيما يلي:

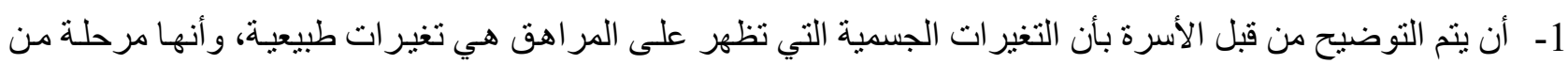

$$
\text { مر احل النمو العادية في حياة أي إنسان. }
$$

2- غرس القيم الدينية في نفوس المر اهقين وتعميقها وحثهم على الالتز ام بها من خلال ممارستهم للشعائر الدينيـة كالصـلاة

$$
\text { بالمسجد وقر اءة الكتب الدينية. }
$$

3- حث المر اهقين على القراءة في سير العظماء و العلماء، كي يستفيدو اويتعلمو اويكتسبو ا منهم بعض الصفات الإيجابية. 4- تشيع المر اهقين على ممارسة الأنشطة الرياضية و الاجتماعية والثقافية و الفنية لتنمية المو اهب و الهو ايات للديهم، وكذلك حضور المحاضر ات الثقافية والندوات الدينية مع حرص الو الدين باستمر ار على مناقتـة أبنـائهم فيمـا قر أوه أو استمعو التهو

$$
\text { إليه وسماع آر ائهم حول ذلك. }
$$

5- اتخاذ الأسرة للمر اهف كصديق مثل اصطحابه لبعض الرحلات و التنزه في المناطق الخلوية، كل ذلك يوفر الفرصة لزيادة

$$
\text { للتقة و الحب المنبادل بين الأسرة و المر اهق. }
$$


المجلة الدولية لنشر البحوث والدراسات

International Journal of Research and Studies Publishing
المجلد الثالث - الإصدار السادس والعشرون تأريخ الإصدار: 20 ديسمبر 2021م

6- ضـرورة الابتعـاد عن النز اعات و الخلافـات وعدم اللجوء إلى مـا يعرف بالتحالفات داخل الأسرة، فمن الضـروري أن يصبح الآباء للمر اهق القدوة الحسنة، وأن يوقن الآباء بأن أبنائهما المر اهقين يحتاجون الحنـان و الحب و العطف و التقدير

$$
\text { و التشجيع أكثر من العنف و القسوة. }
$$

7- سر عة المبادرة لاكتشاف ما يعاني منه المر اهق من مشكلات أو عثرات، و التي تظهر لها بعض العلامات عليه كسرحانه أو عدم تركيزه، ومن ثم يجب سرعة البدء في توجيه الرعاية الفردية إلبه.

3. الإجراءات المنهجية للاراسة 1.3 - 1.3 نوع الدراسة:

تعتبر هذه الدر اسة من الدراسات الوصفية حيث تستهدف الدراسات الوصفية تقرير خصـائص ظـاهرة معينة أو موقف تغلب عليه صفة التحديد، وتعتمد على جمع الحقائق وتحليلها وتفسير ها لاستخلاص دلالتها، وتصل من خلال ذلك إلى إصدار التعليمات بشأن الموقف أو الظاهرة التي يقوم الباحث بدر استها (حسن، 1990، 198).

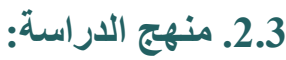

اعتمدت الدر اسة على منهج المسح الاجتماعي بأسلوب العينة، وذلك لأنه من المناهج الرئيسية في الدراسـات الوصفية التحليلية، حيث يعرف بأنه أحد المناهج الرئيسية التي تستخدم في الدراسـات الوصفية، ويوفر الكثير من البيانات و المعلومـات

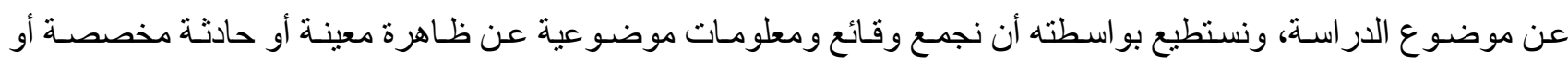
جماعة من الجماعات أو ناحية من النواحي (الصحية، التربوية، الاجتماعية ... الخ) (مختار، 1995، 156) 3.3. مجتمع وعينة الار اسةة: يتكون مجتمع الدر اسة من أباء وأمهات لمر اهقين بمحافظة جده، وأستخدم الباحث أسلوب العينة العشوائية البسيطة،

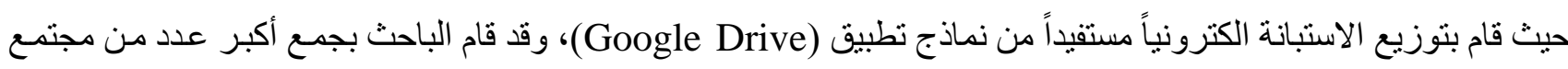
الدراسة الكلي، حيث تجاوب مع الباحث عدد (226) مبحوثاً بمثلون عبنة الدراسة.

4.3. - 2.3 مجالات الاراسة:

تتحدد مجالات الدراسة فيما يلي:

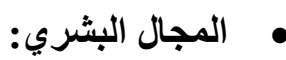
عينة عشو ائية من آباء و أمهات لمر اهقين بمحافظة جدة، و عددهم (226) مفردة.

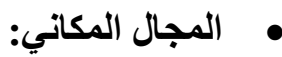
تم تطبيق الدر اسة الميدانية بمحافظة جدة بالمملكة العربية السعودية وذلك لأن الباحث يعد أحد سكان محافظة جدة ممـا يسهـل عليه من مهمة جمع بيانات الدراسة.

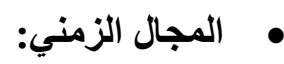

تم جمع البيانات لهذه الدر اسة خلال أسبو عين من الفترة الزمنية 2021/3/15م الى 2021/4/1م 
المجلة الدولية لنشر البحوث والدراسات

International Journal of Research and Studies Publishing

ISSN: 2709-7064
المجلد الثالث - الإصدار السادس والعشرون تأريخ الإصدار: 20 ديسمبر 2021م

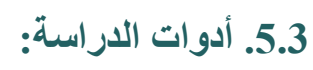

بمـا أن وسيلة جمع المعلومـات من أهم مر احل الإجر اءات المنهجيـة في كل بحث، وبو اسطتها و عن طريق حسن

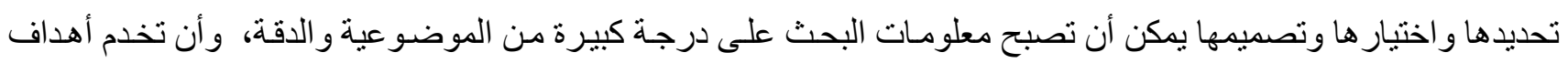

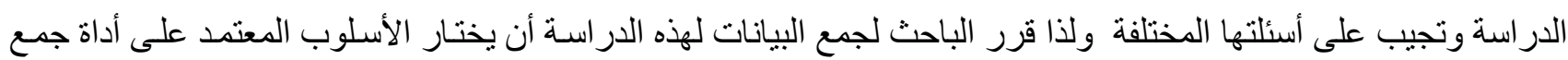
البيانات من المبحوثين و هي (استبانة) والتي تعني مجموعة من الأسئلة المكتوبـة بغرض استطلاع الر أي أو جمع المعلومـات حول موضوع معين، و هذه الأداة (الاستبانة) تستطيع أن تعكس و اقع المشكلة من ناحية، وتجيب على تسـاؤلات الدر اسـة من ناحية أخرى بعد أن تم الاطلاع على الإطار النظري و الدر اسات السابقة والاسترشاد ببعض الأدوات الموجودة في هذا المجال. خطوات إعداد أداة الاراسة وجمع البيانات: بعد تحديد هدف الدر اسة وهو التعرف على مشكلات مرحلة المر اهقة و أثر ها على الاستقر ار الأسري، تم تصميم مجموعة من الأسئلة تختص بموضوع الدر اسة بعد الاطلاع على أدبيات الدر اسة و الدر اسات السابقة، حيث تكونت الاستبانة من الأجز اء

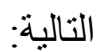

\section{• القسم الأول: البيانات الأساسية.}

ويشتمل على البيانات الأوليـة لعينـة الدر اسـة مثل (الجنس، ترتيب المر اهق داخل الأسرة، المستوى الدر اسـي العـام للمر اهق، المستوى التعليمي للو الد/ة، الوضع الاقتصادي للأسرة).

$$
\text { • القسم الثاني: محاور الاراسة. }
$$

و اشتمل على (43) فقرة مقسمة إلى خمسة محاور على النحو التالي:

- ـ ـ المحور الأول: أهم مشكلات المر اهق مع افر اد أسرته من وجهة نظر الو الدين، واشتمل على (8) فقرات.

- - المحور الثاني: المشكلات النفسية التي تواجه المر اهقين من وجهة نظر الوالدين، واثتمل على (8) فقرات.

- - ـ المحور الثالث: المشكلات الاجتماعية التي تواجه المر اهقين من وجهة نظر الوالدين، واثتمل على (9) فقرات.

- - المحور الر ابع: المشكلات الدراسية التي تواجه المر اهقين من وجهة نظر الوالدين، واشتمل على (6) فقرات.

- - المحور الخامس: الاثار المترنبة على الاستقرار الاسري من مشكلات مرحلة المر اهقة، واشتمل على (12) فقرة.

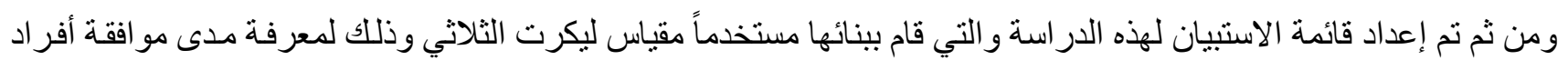
العينة على عبار ات أداة الدر اسة وذللك وفقاً للجدول التالي:

\begin{tabular}{|c|c|c|c|}
\hline درجة الموافقة & الإجابة & الوزن & المدى \\
\hline ضتعيفة & لا أو افق & 1 & من 1 إلى 1.67 \\
\hline متوسطة & لا اعلم & 2 & من 1.67 إلى 2.33 \\
\hline كبيرة & أو افق & 3 & من 2.33 إلى 3 \\
\hline
\end{tabular}

\section{جدول رقم (3-1) يوضح توزيع أوزان ومدى العبارات حسب مقياس ليكرت}


المجلة الدولية لنشر البحوث والدراسات

International Journal of Research and Studies Publishing

ISSN: 2709-7064
المجلد الثالث - الإصدار السادس والعشرون تأريخ الإصدار: 20 ديسمبر 2021م

إجراعات الصدق والثبات لأداة الدراسة:

أولاً: إجراءات الصدق. - ماءقات

(أ) صدق التكوين (الصدق الظاهري).

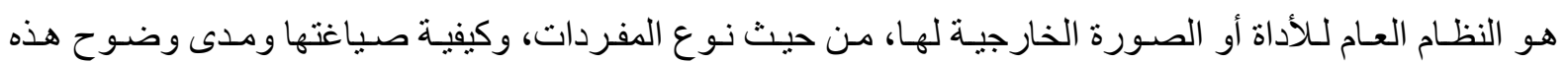

المفردات، كذللك يتناول تعليمات الاستبانة ومدى دقتها ودرجة ما تتمتع به من موضو عية كما يشير هذا النوع من الصدق إلى أن الاستبانة مناسبة للغرض الذي وضعت من أجله.

(ب) صدق المحتوى: (ب)

يقصد بالاتسـاق الداخلي لأسئلة الاستبانة هي قوة الارتباط بين درجات كل مجـال ودرجات أسئلة الاستبانة الكلية، و الصدق ببساطة هو أن تقيس أسئلة الاستبانة أو الاختبار مـاوضعت لقياسـه أي يقيس فعـا الوظيفة التي يفترض أنسه يقيسها، وسيتم التأكد من صدق الاتساق الداخلي للاسنبانة بحسـاب معاملات ارتباط بيرسون بين فقر ات الاستبانة و الدرجة الكلية لها والنتائج موضحة في الجدول التالي:

جدول رقم (3-2) يوضح معاملات ارتباط بيرسون لكل فقرة من فقرات الاستبانة مع الدرجة الكلية

\begin{tabular}{|c|c|c|c|c|c|c|c|c|c|}
\hline \multicolumn{2}{|c|}{ 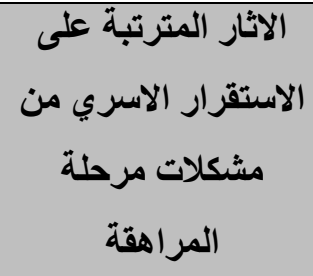 } & \multicolumn{2}{|c|}{ من التي تواجه المراهلات الدراسية } & \multicolumn{2}{|c|}{ التي تواجهلات الاجتماعية المراهقين } & \multicolumn{2}{|c|}{ 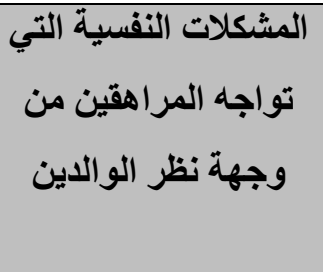 } & \multicolumn{2}{|c|}{ وأهم مشكلات المراهت } \\
\hline الارتباط معامل & رقبارة & الارتباط معامل & رقبارة & الارتباط معامل & العبارة & الارتباط معامل & رقبارة & الارتباط معامل & العبارة \\
\hline $.222(* *)$ & 1 & $.475(* *)$ & 1 & $.577(* *)$ & 1 & $.563(* *)$ & 1 & $.527(* *)$ & 1 \\
\hline $.565(* *)$ & 2 & $.552(* *)$ & 2 & $.571(* *)$ & 2 & $.403(* *)$ & 2 & $.496(* *)$ & 2 \\
\hline $.615(* *)$ & 3 & $.544(* *)$ & 3 & $.429(* *)$ & 3 & $.381(* *)$ & 3 & $.402(* *)$ & 3 \\
\hline $.663(* *)$ & 4 & $.528(* *)$ & 4 & $.598(* *)$ & 4 & $.431(* *)$ & 4 & $.494(* *)$ & 4 \\
\hline $.559(* *)$ & 5 & $.440(* *)$ & 5 & $.477(* *)$ & 5 & $.604(* *)$ & 5 & $.534(* *)$ & 5 \\
\hline $.424(* *)$ & 6 & $.615(* *)$ & 6 & $.472(* *)$ & 6 & $.604(* *)$ & 6 & $.540(* *)$ & 6 \\
\hline $.675(* *)$ & 7 & & & $.558(* *)$ & 7 & $.305(* *)$ & 7 & $.566(* *)$ & 7 \\
\hline $.399(* *)$ & 8 & & & $.500(* *)$ & 8 & $.456(* *)$ & 8 & $.502(* *)$ & 8 \\
\hline $.675(* *)$ & 9 & & & $.592(* *)$ & 9 & & & & \\
\hline $.528(* *)$ & 10 & & & & & & & & \\
\hline $.563(* *)$ & 11 & & & & & & & & \\
\hline $.482(* *)$ & 12 & & & & & & & & \\
\hline
\end{tabular}


المجلة الدولية لنشر البحوث والدراسات

International Journal of Research and Studies Publishing
المجلد الثالث - الإصدار السادس والعشرون تأريخ الإصدار: 20 ديسمبر 2021م

من نتائج الجدول أعلاه تبين أن معاملات الارتباط بين كل عبارة من عبار ات أداة الدر اسـة والدرجة الكلية للأداة نجد أن جميع معاملات كانت إيجابية وذات دلالة إحصائية، مما يعني أن هناك اتساق داخلي بين كل عبارة و الدرجة الكلية.

(ج) صدق المحكمين: ( ) (ج)

للتحقق من صدق محتوى أداة الاستبانة، نم عرضها على مجموعة من المحكمين و المختصبين في الخدمـة الاجتماعية

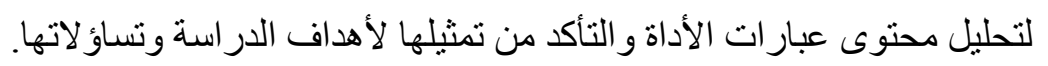
ثانياً: ثبات الأداة.

يثثير الثبات إلى مدى قدرة المقياس على إعطاء نفس النتائج في حالة تطبيقه مرة أخرى في ظروف مماثلة، ويتم التحقق مـن ثبـات اسـتبانة الدر اسـة عـن طريـق اسـتخر اج معامـل ألفـا كرونبـاخ باسـتخدام برنـامج الحزم الإحصــائية الخـاص بـالعلوم الاجتماعية SPSS

\section{جدول (3-3) يوضح معامل ألفا كرونباخ لمحاور أداة الدراسة}

\begin{tabular}{|c|c|c|}
\hline الفاكرونباخ & 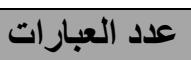 & 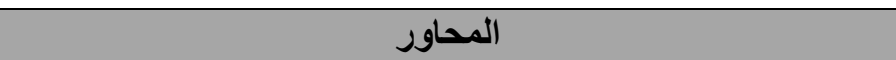 \\
\hline 0.796 & 8 & أهم مشكلات المر اهق مع افر اد أسرته من وجهة نظر الو الدين. \\
\hline 0.738 & 8 & المشكلات النفسية التي تو اجه المر اهقين من وجهة نظر الو الدين. \\
\hline 0.814 & 9 & المشكلات الاجتماعية التي تو اجه المر اهقين من وجهة نظر الو الدين. \\
\hline 0.732 & 6 & المشكلات الدراسية التي تو اجه المر اهقين من وجهة نظر الوالدين. \\
\hline 0.612 & 12 & الاثار المترتبة على الاستقرار الاسري من مشكلات مرحلة المر اهقة \\
\hline 0918 & 43 & \\
\hline
\end{tabular}

الجدول أعلاه بيّن معاملات ألفا كرونباخ للمحاور تر اوحت مـا بين (0.814-0.612) وللأداة ككل بلغت (0.918) وهي قيم مرتفعة جداً ما يعني أن هناك ثبات عالي لأداة الدر اسة، أب يمكن الاعتماد عليها من حيث جمع البيانات وكذلك تعميم النتائج. 6.3. الأساليب الإحصائية المستخدمة:

تم ترميز الاستبيانات و إدخالها في الحاسب الآلي باستخدام برنـامج الحزمة الإحصـائية للعلوم الاجتماعية (SPSS) وذلك بغرض تحليل بيانات الدر اسة تحليلاً علمياً يحقق أهداف الدر اسة ويجيب عن تساؤ لاتها وقد استخدم الباحث الاختبار ات التالية: 1. المتوسطات الحسابية و الانحر افات المعيارية لترتيب إجابات مفردات الدراسة لعبار ات الاستبانة حسب درجة المو افقة. 2. معامل ارتباط بيرسون (Pearson) لإيجاد العلاقة بين بعض المتغير ات وكذلك إيجاد معامل الاتسـاق الداخلي وتحديد نوع العلاقة بين المتغير ات و الدرجة الكلية للأداة وكذللك للإجابة على الفرضيات. 3. معامل الفا كرونباخ (ALPHA) لحساب ثبات محاور الدر اسة وأداة الدر اسة ككل. Independent sample t-test اختبار (t) للعينتين المنفصلتين 5. One Way ANOVA اختبار تحليل التباين الأحادي 
المجلة الدولية لنشر البحوث والدراسات

International Journal of Research and Studies Publishing

ISSN: 2709-7064
المجلد الثالث - الإصدار السادس والعشرون تأريخ الإصدار: 20 ديسمبر 2021م

$$
\begin{aligned}
& \text { 4. عرض وتفسير نتائج الاراسة } \\
& \text { 1.4. وصف عينة الاراسة. } \\
& \text { 1- نوع الجنس للمراهق }
\end{aligned}
$$

\begin{tabular}{|c|c|c|}
\hline النسبة & التكرار & الفئة \\
\hline 58.4 & 133 & ذكر \\
\hline 41.6 & 93 & أنثى \\
\hline 100 & 226 & المجموع \\
\hline
\end{tabular}

جدول (1-4) توزيع أفراد العينة على حسب نوع الجنس للمراهق

الجدول أعلاه عبارة عن النسب والتكرارات لنوزيع أفر اد العينة على حسب نوع الجنس للمر اهق، فنجد أن الغالبيـة ذكور بنسبة (58.4\%) بينما بلغت نسبة الاناث (41.6\%) الثكل التالي بيين هذه النسب:

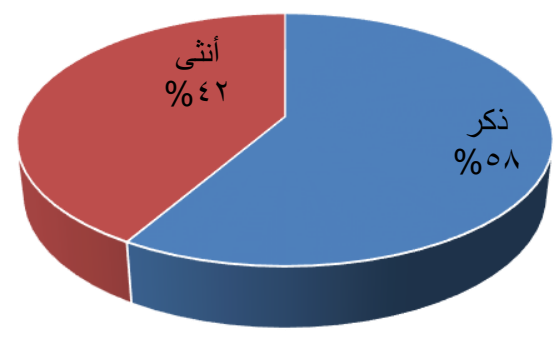

شكل (1-4) توزيع أفراد العينة على حسب نوع الجنس للمر اهق

\begin{tabular}{|c|c|c|}
\hline النسبة & التكرار & الترتيب \\
\hline 31.0 & 70 & الأول \\
\hline 22.1 & 50 & الثاني \\
\hline 17.7 & 40 & الثالث \\
\hline 12.4 & 28 & الر ابع \\
\hline 7.1 & 16 & الخامس \\
\hline 9.7 & 22 & غير ذللك \\
\hline 100 & 226 & المجموع \\
\hline
\end{tabular}

2- - ترتيب المراهق بين اخوته:

جدول رقم (4-2) توزيع أفراد العينة على حسب ترتيب المراهق بين اخوته. 
المجلة الدولية لنشر البحوث والدراسات

International Journal of Research and Studies Publishing
المجلد الثالث - الإصدار السادس والعشرون تأريخ الإصدار: 20 ديسمبر 2021م

الجدول أعلاه عبـارة عن النسب والتكر ارات لتوزيع أفر اد العينـة على حسب ترتيب المر اهق بين أخوتـه، فنجد أن الغالبيـة الترتيب الأول بنسبة (31\%)، ومن ثم الثاني بنسبة (22.1\%)، يليه الترتيب الثالث بنسبة (17.7\%)، ومن ثم الر ابع بنسبة (12.4\%)، يليه غير ذلك بنسبة (9.7\%)، وأخيراً الترتيب الخامس بنسبة (7.1\%)، الثكل التالي يبين

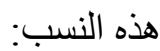

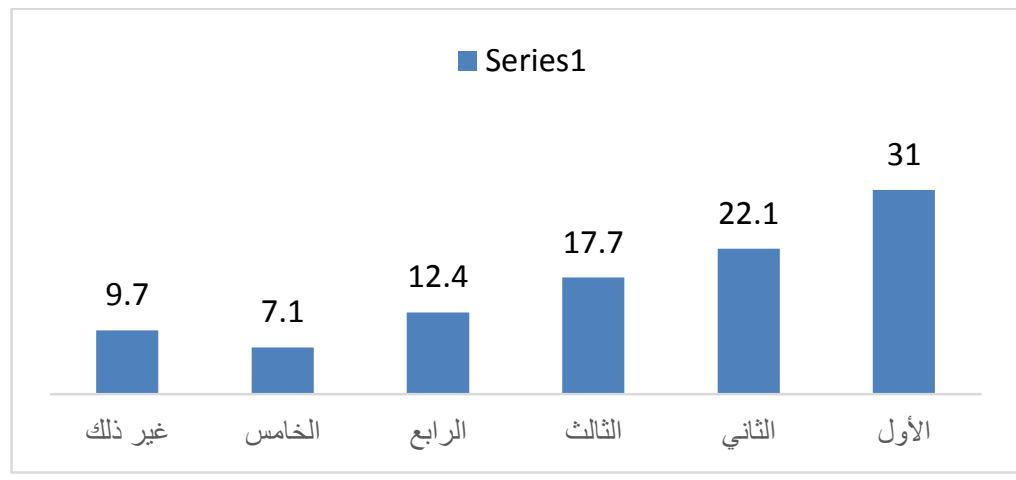

شكل رقم (4-2) توزيع أفراد العينة على حسب ترتيب المراهق بين اخوته.

$$
\text { 3- - المستوى الاراسي العام للمراهق: }
$$

جدول رقم (4-3) توزيع أفراد العينة حسب المستوى الاراسي العام للمراهق.

\begin{tabular}{|c|c|c|}
\hline النسبه & التكرار & المستوى \\
\hline 5.3 & 12 & ضعيف \\
\hline 48.2 & 109 & متوسط \\
\hline 46.5 & 105 & ممتاز \\
\hline 100 & 226 & المجموع \\
\hline
\end{tabular}

الجدول أعلاه عبارة عن النسب والتكر ارات لتوزيع أفر اد العينة على حسب المستويات الدراسية للمر اهق فنجد أن الغالبية مستو اهم التعليمي متوسط بنسبة (48.2\%)، ومن ثم ممتاز بنسبة (46.5\%)، و أخير اً المستوى ضعيف بنسبة (5.3\%)، الثكل

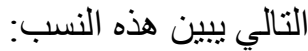

\section{- Series1}

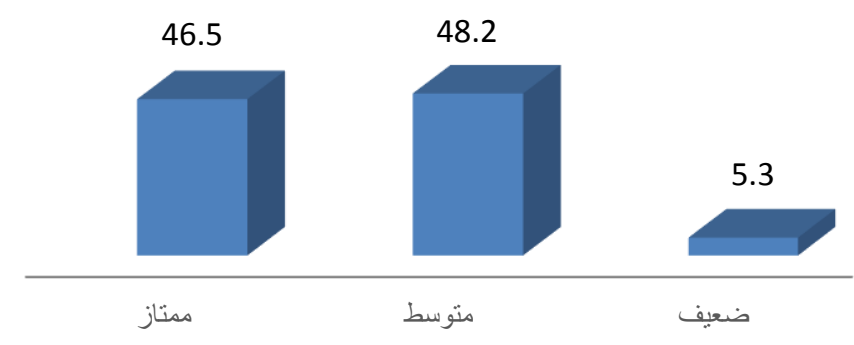

شكل رقم (4-3) توزيع أفراد العينة حسب المستوى الاراسي العام للمراهق. 
المجلة الدولية لنشر البحوث والدراسات

International Journal of Research and Studies Publishing

ISSN: 2709-7064
المجلد الثالث - الإصدار السادس والعشرون تأريخ الإصدار: 20 ديسمبر 2021م

4) المستوى التعليمي للوالد/ة:

جدول رقم (4-4) توزيع أفراد العينة حسب المستوى التطليمي للوالد/ة.

\begin{tabular}{|c|c|c|}
\hline النسبة & التكرار & المستوى \\
\hline 2.2 & 5 & لا يقر أو لا يكتب \\
\hline 11.9 & 27 & تعليم ابتدائي \\
\hline 8.4 & 19 & تعليم متوسط \\
\hline 29.2 & 66 & تعليم ثانوي \\
\hline 48.2 & 109 & تعليم جامعي فأعلى \\
\hline 100 & 226 & المجموع \\
\hline
\end{tabular}

الجدول أعـلاه عبـارة عن النسـب و التكر ارات لتوزيـع أفر اد العينـة على حسب المسـتوى التعليمي للو الدين فنجد أن الغالبيـة مستو اهم التعليمي جامعي فأعلي بنسبة (48.2\%)ومن ثم التعليم الثانوي بنسبة (29.2\%) يليه تعليم ابتدائي بنسبة (11.9\%) ومن ثم تعليم متوسط بنسبة بلغت (8.4\%)، و أخير اً لا يقر أ و لا يكتب بنسبة بلغت (2.2\%)، الثكل التالي يبين هذه النسب:

\section{- Series1}

48.2

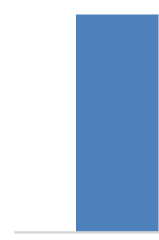

29.2

تعليم جامعي فأعلى

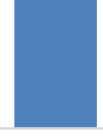

$$
8.4
$$

11.9
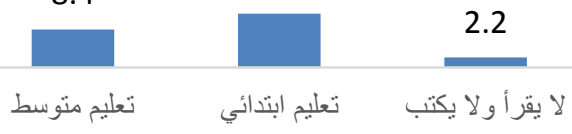

شكل رقم (4-4) توزيع أفراد العينة حسب المستوى التعليمي للوالداة.

4- - الوضع الاقتصادي للأسرة:

جدول رقم (4-5) توزيع أفراد العينة على حسب الوضع الاقتصادي للأسرة.

\begin{tabular}{|c|c|c|}
\hline النسبة & التكرار & الوضع \\
\hline 1.3 & 3 & ضعيف \\
\hline 81.9 & 185 & متوسط \\
\hline 16.8 & 38 & مرتفع \\
\hline 100 & 226 & المجموع \\
\hline
\end{tabular}

يبين الجدول أعلاه أن أغلب أفر اد العينـة أوضـاعهم الاقتصـادية متوسطة بنسبة (81.9\%)، ومن ثم مرتفعي الدخل بنسبة (16.8\%)، بينما بلغت نسبة ضعيفي الدخل (1.3\%)، الشكل التالي يبين هذه النسب: 
المجلة الدولية لنشر البحوث والدراسات

International Journal of Research and Studies Publishing

ISSN: 2709-7064
المجلد الثالث - الإصدار السادس والعشرون تأريخ الإصدار: 20 ت 20 ديسمبر 2021م

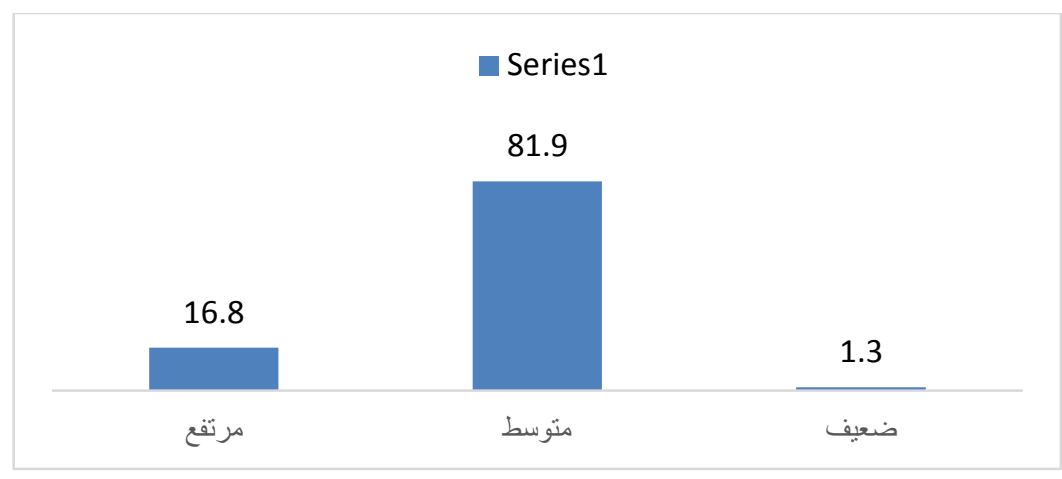

شكل رقم (4-5) توزيع أفراد العينة على حسب الوضع الاقتصادي للأسرة.

2.4 محاور الاراسة.

النتائج المتعلقة بالسؤال الأول:

نص السؤال الأول على "ما هي أهم مشكلات المراهق مع أفراد أسرته من وجهة نظر الوالدين؟".

للإجابـة على السؤال الأول تم استخدام المتوسطات الحسـابية والانحر افـات المعياريـة لعبار ات المحور الأول" أهم مشكلات المر اهق مع افر اد أسرته من وجهة نظر الوالدين" كما يوضح الجدول التالي: جدول (4-6) المتوسطات الحسابية والانحر (فات المعيارية لإجابات أفراد العينة على عبار ات أهم مشكلات المراهق مع افراد أسرته

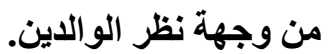

\begin{tabular}{|c|c|c|c|c|c|}
\hline 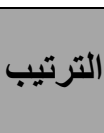 & لدرجة الموافقة & النسبن & الالمعراف & المتوسط المت & 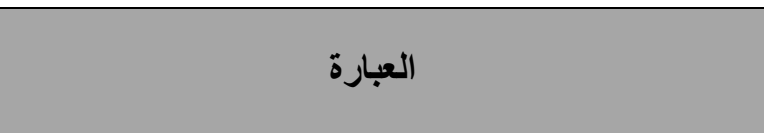 \\
\hline 7 & منوسطة & 67.7 & 0.95 & 2.03 & ينتاجر مع أسرته كثير ا وبشكل مستمر \\
\hline 3 & كبيرة & 78.0 & 0.92 & 2.34 & يتحاور مع والديه بصوت مرتفع. \\
\hline 1 & كبيرة & 83.0 & 0.84 & 2.49 & ينفرد بنفسه لوقت طويل. \\
\hline 5 & متوسطة & 72.0 & 0.95 & 2.16 & برفض مشاركة افر اد اسرته في حاجاته. \\
\hline 4 & منوسطة & 74.3 & 0.94 & 2.23 & يستخدم القوة في التعامل مع إخوته. \\
\hline 2 & كبيرة & 81.3 & 0.88 & 2.44 & يثور ويغضب لأتفه الأسباب. \\
\hline 6 & منوسطة & 72.0 & 0.93 & 2.16 & دائما ما يتو عد اخوته بالانتقام عند حدوث أي خلاف معهح. \\
\hline \multirow[t]{2}{*}{8} & ضعيفة & 51.0 & 0.84 & 1.53 & يخرج من المنزل مباشرة لمجرد حدوث اي مشكلة. \\
\hline & متوسطة & 72.4 & 0.91 & 2.17 & 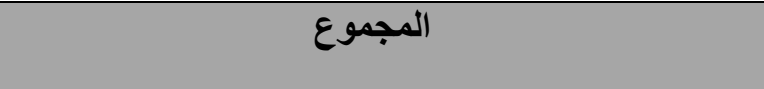 \\
\hline
\end{tabular}

الجدول أعلاه عبارة عن المنوسطات الحسابية والانحر افات المعيارية لإجابات أفر اد العينة على أهم مشكلات المر اهق مع افراد أسرته من وجهة نظر الو الدين فنجد أن المتوسط العام بلغ (2.17من 3) بانحر اف معياري (0.91) 
المجلة الدولية لنشر البحوث والدراسات

International Journal of Research and Studies Publishing
المجلد الثالث - الإصدار السادس والعشرون تأريخ الإصدار: 20 ديسمبر 2021م

ISSN: 2709-7064

و المتوسطات تقع بداخل الفئة الثانيـة لمعيار ليكرت الثثلاتي (1.67 إلى 2.33) و التي تعنـي أن أفر اد العينـة مو افقين

بدرجة منوسطة على محور " أهم مشكلات المر اهق مع افر اد أسرته من وجهة نظر الوالدين".

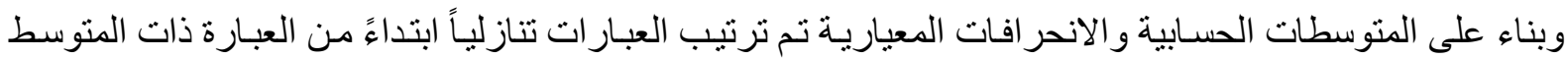

الأكبر و انتهاء بالعبارة ذات المتوسط الأصغر فنجد أن العبارة (ينفرد بنفسه لوقت طويل) بمتوسط بلغ (2.49) ودرجـة مو افقة كبيرة، ومن ثم العبارة (يثور ويغضب لأتفه الأسباب) بمتوسط بلغ (2.44) ودرجة مو افقة كبيرة، تليها العبارة (يتحاور مـع و الديـه بصوت مرتفع.) بمتوسط بلغ (2.34) ودرجة مو افقة كبيرة، ومن ثم العبارة (يستخدم القوة في التعامل مـع إخوتـه) بمتوسط بلغ (2.23) ودرجة مو افقة متوسطة، تليها العبارة (يرفض مشـاركة افر اد اسرته في حاجاته) بمتوسط بلغ (2.16) ودرجة مو افقة منوسطة، ومن ثم العبارة (دائما ما يتو عد اخوته بالانتقام عند حدوث أي خلاف معهم) بمتوسط بلغ (2.16)، تليها العبارة (يتشـاجر مـع أسرته كثير ا وبشكل مستمر ) بمنوسط بلغ (2.03) و اخير اً العبارة (يخرج من المنزل مباشـرة لمجرد حدوث اي مشكلة) بمنوسط بلغ (1.53) ودرجة مو افقة ضعيفة. النتائج المتعلقة بالسؤال الثاني:

نص السؤال الثاني على "ما هي المشكلات النفسية التي تواجه المراهقين من وجهة نظر الوالدين؟" للإجابة على السؤال الثاني تم استخدام المتوسطات الحسـابية والانحر افات المعياريـة لعبـار ات المحور الثاني" المشكلات النفسية التي تو اجه المر اهقين من وجهة نظر الوالدين " كما يوضح الجدول التالي: جدول (4-7) المتوسطات الحسابية والانحرافات المعيارية لإجابات أفراد العينة على عبارات محور المشكلات النفسية التي تواجه المراهقين من وجهة نظر الوالدين.

\begin{tabular}{|c|c|c|c|c|c|}
\hline 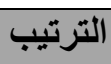 & درجة الموافقة & الزون النسبي & الانحر اف المعياري & المتوسط & 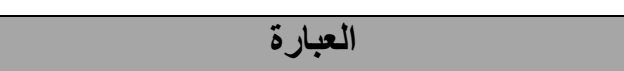 \\
\hline 3 & منوسطة & 69.67 & 0.91 & 2.09 & يشعر بالضيق و التوتر و القلق داخل المنزل. \\
\hline 2 & كبيرة & 78.00 & 0.87 & 2.34 & يخاف من انتقاد الاخرين له. \\
\hline 5 & منوسطة & 65.00 & 0.92 & 1.95 & ليس لديه الجر أة الكافية في الحديث مع الآخرين. \\
\hline 7 & متوسطة & 56.67 & 0.87 & 1.70 & يعاني من صعوبة التركيز و الانتباه. \\
\hline 6 & متوسطة & 64.00 & 0.89 & 1.92 & يشعر باستمر ار بعدم الراحة النفسية. \\
\hline 1 & كبيرة & 81.00 & 0.85 & 2.43 & يعاني من سر عة الانفعال و الغضب. \\
\hline 4 & متوسطة & 67.00 & 0.91 & 2.01 & يتجاهل الكثير من المو اقف نتيجة الخجل. \\
\hline 8 & متوسطة & 49.33 & 0.79 & 1.48 & يشعر بالخوف عند الحديث مع افراد اسرته. \\
\hline & متوسطة & 66.33 & 0.88 & 1.99 & المجموع \\
\hline
\end{tabular}

الجدول أعلاه عبارة عن المتوسطات الحسابية و الانحر افات المعياريـة لإجابـات أفر اد العينـة على عبـار ات المشكلات النفسية الني تواجه المر اهقين من وجهة نظر الوالدين، 
المجلة الدولية لنشر البحوث والدراسات

International Journal of Research and Studies Publishing
المجلد الثالث - الإصدار السادس والعشرون تأريخ الإصدار: 20 ديسمبر 2021م

فنجد أن المتوسط العـام بلـغ (1.99 من 3) بـانحر اف معيـاري (0.88) و المتوسطات تقع بداخل الفئة الثانيـة لمعيار

ليكرت الثلاثي (1.67 إلى 2.33) و التي تعني أن أفر اد العينة مو افقين بدرجة متوسطة على عبار ات محور " المشكلات النفسية التي تو اجه المر اهقين من وجهة نظر الو الدين".

وبناء على المتوسطات الحسـابية و الانحر افات المعياريـة تم ترتيب العبار ات تنازلياً ابتداءً من العبـارة ذات المتوسط

الأكبر و انتهاء بالعبارة ذات المتوسط الأصغر فنجد أن العبارة (يعاني من سر عة الانفعال و الغضب) بمتوسط بلغ (2.43) ودرجـة مو افقة كبيرة، ومن ثم العبـارة (يخـاف من انتقاد الاخرين له)بمتوسط بلغ (2.34) ودرجـة مو افقة كبيرة، تليها العبارة (يشـعر بالضيق و التوتر و القلق داخل المنزل) بمنوسط بلغ (2.09) ودرجة مو افقة منوسطة، ومن ثم العبارة (يتجاهل الكثير من المواقف نتيجة الخجل) بمتوسط بلغ (2.01) ودرجة مو افقة متوسطة، تليها العبارة (ليس لايسه الجر أة الكافيـة في الحديث مـع الآخرين) بمتوسط بلغ (1.95) ودرجة مو افقة منوسطة، ومن ثم (يشعر باستمر ار بعدم الر احة النفسية) بمتوسط بلـغ (1.92) ودرجة مو افقة منوسطة، ومن ثم العبارة (يعاني من صعوبة التركيز و الانتباه) بمنوسط بلغ (1.70) ودرجة مو افقة متوسطة، واخيراً العبارة (يشعر بالخوف عند الحديث مع افر اد أسرته) بمتوسط بلغ (1.48) ودرجة موافقة متوسطة.

\section{النتائج المتعلقة بالسؤال الثالث:}

نص السؤال الثالث على "ما هي المشكلات الاجتماعية التي تواجه المراهقين من وجهة نظر الوالدين؟"

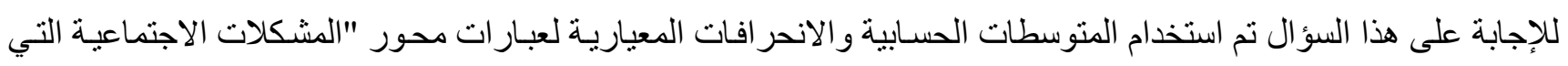
تو اجه المر اهقين من وجهة نظر الو الدين " كما يلي: جدول (4-8) المتوسطات الحسابية والانحرافات المعيارية لإجابات أفراد العينة على عبارات محور المشكلات الاجتماعية التي تواجه المراهقين من وجهة نظر الوالدين.

\begin{tabular}{|c|c|c|c|c|c|}
\hline الترتيب & الموافقة & النسبي & الالمعراف & المتوسط & 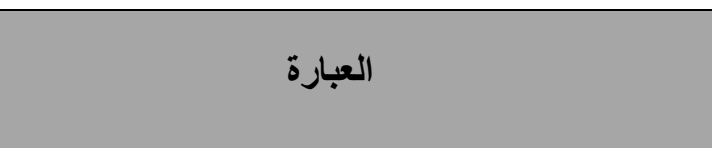 \\
\hline 1 & متوسطة & 71.33 & 0.94 & 2.14 & يلجأ للكذب للظهور بصورة لائقة أمام الآخرين. \\
\hline 7 & متوسطة & 56.33 & 0.84 & 1.69 & تتسم علاقاته مع الآخرين بالتوتر. \\
\hline 4 & متوسطة & 64.00 & 0.93 & 1.92 & يتجنب المشاركة في الأنشطة الاجنماعية مع الآخرين. \\
\hline 8 & متوسطة & 62.67 & 0.92 & 1.88 & تتنابه نوبات من فقدان السيطرة على نفسه. \\
\hline 2 & متوسطة & 68.00 & 0.92 & 2.04 & يفتقر للمهار ات الاجتماعية. \\
\hline 3 & 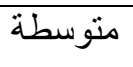 & 65.00 & 0.95 & 1.95 & عندما يغضب يتلفظ بكلام غير لائق. \\
\hline 6 & متوسطة & 58.67 & 0.91 & 1.76 & يندفع للمشاجر ات بدون سبب. \\
\hline 9 & ضعيفة & 43.67 & 0.67 & 1.31 & يتلف الممنلكات العامة و الخاصة للأخرين. \\
\hline \multirow[t]{2}{*}{5} & متوسطة & 64 & 0.93 & 1.92 & يبرر أخطائه بالكذب على الآخرين. \\
\hline & متوسطة & 61.52 & 0.89 & 1.85 & 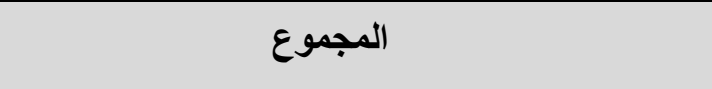 \\
\hline
\end{tabular}


المجلة الدولية لنشر البحوث والدراسات

International Journal of Research and Studies Publishing
المجلد الثالث - الإصدار السادس والعشرون تأريخ الإصدار: 20 ديسمبر 2021م

الجدول أعلاه عبارة عن المتوسطات الحسابية و الانحر افات المعياريـة لإجابـات أفر اد العينـة على عبـار ات المشكلات

الاجتماعية التي تواجه المر اهقين من وجهة نظر الو الدين، فنجد أن المتوسط العام بلغ (1.85من 3) بانحر اف معياري (0.89) و المتوسطات تقع بداخل الفئة الثانية لمعيار ليكرت الثلاثي (1.67 إلى 2.33) و التي تعني أن أفر اد العينة مو افقين بدرجهة متوسطة على فقرات محور " المشكلات الاجتماعية التي تواجه المر اهقين من وجهة نظر الو الدين ". وبناء على المنوسطات الحسـابية والانحر افات المعياريـة تم ترتيب العبار ات تنازلياً ابتداءً من العبارة ذات المتوسط الأكبر و انتهاء بالعبارة ذات المتوسط الأصـر فنجد أن العبارة (يلجأ للكذب للظهور بصورة لائقة أمسام الآخرين) بمنوسط بلغ (2.14) ودرجة مو افقة منوسطة، ومن ثم العبارة (يفتقر للمهار ات الاجتماعية)بمتوسط بلغ (2.04) ودرجة مو افقة متوسطة، تليها العبارة (عندما يغضب يتلفظ بكلام غير لائق) بمتوسط بلغ (1.95) ودرجة مو افقة متوسطة، ومن ثم العبارة (يتجنب المشـاركة في

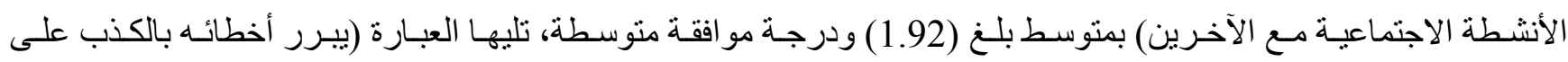
الاخرين) بمتوسط بلغ (1.92) ودرجة مو افقة متوسطة، ومن ثم (يندفع للمشـاجر ات بدون سبب) بمنوسط بلغ (1.76) ودرجة مو افقة متوسطة، ثم العبارة (تتسم علاقاته مع الآخرين بالتوتر) بمتوسط بلغ (1.69) ودرجة مو افقة منوسطة، تليها العبارة (تتتابه نوبـات من فقدان السبطرة على نفسـه) بمتوسط بلـغ (1.88) ودرجـة مو افقة متوسطة، وأخيراً العبارة (يتلف الممتلكات العامـة و الخاصة للأخرين) بمتوسط بلغ (1.31) ودرجة مو افقة ضعيفة.

\section{النتائج المتعلقة بالسؤال الرابع:}

نص السؤال الرابع على" ما هي المشكلات الدراسية التي تواجه المراهقين من وجهة نظر الوالدين ؟: للإجابة على هذا التساؤل تم استخدام المتوسطات الحسابية والانحر افات المعيارية لعبار ات محور "المشكلات الدر اسية التي تواجـهـ المر اهقين من وجهة نظر الو الدين" كما يلي:

جدول (4-9) المتوسطات الحسابية والانحرافات المعيارية لإجابات أفراد العينة على عبارات محور المشكلات الدراسية التي تواجه المراهقين من وجهة نظر الوالدين.

\begin{tabular}{|c|c|c|c|c|c|}
\hline الترتيب & درجة الموافقة & الوزن النسبي & الاتحراف المعياري & المتوسط & العبارة \\
\hline 4 & ضعيفة & 55.0 & 0.90 & 1.65 & يذهب متأخر أ للمدرسة. \\
\hline 2 & متوسطة & 71.7 & 0.94 & 2.15 & قليل الاهتمام بالدروس و الواجبات المنزلية. \\
\hline 6 & ضعيفة & 52.0 & 0.80 & 1.56 & كثير الثكوى من زملائه في الفصل. \\
\hline 5 & ضعيفة & 54.7 & 0.84 & 1.64 & يتمرد على أساتذة المدرسة ولو ائحها النظامية. \\
\hline
\end{tabular}


المجلة الدولية لنشر البحوث والدراسات

International Journal of Research and Studies Publishing

ISSN: 2709-7064
المجلد الثالث - الإصدار السادس والعشرون تأريخ الإصدار: 20 ديسمبر 2021م

\begin{tabular}{|c|c|c|c|c|c|}
\hline 3 & 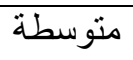 & 69.0 & 0.93 & 2.07 & يشعر بالتوتر النفسي مع اقتر اب موعد الامتحانات. \\
\hline 1 & متوسطة & 72.7 & 0.92 & 2.18 & يعجز عن تنظيم وتخصيص وقت للار اسة. \\
\hline & متوسطة & 62.50 & 0.89 & 1.88 & المجموع \\
\hline
\end{tabular}

الجدول أعلاه عبارة عن المتوسطات الحسابية و الانحر افات المعياريـة لإجابـات أفر اد العينـة على عبـار ات المشكلات الدراسية التي تواجه المـر اهقين من وجهة نظر الو الدين، فنجد أن المتوسط العام بلغ (1.88من 3) بـانحر اف معياري (0.89) و المتوسطات تقع بداخل الفئة الثانية لمعيار ليكرت الثناثي (1.67 إلى 2.33) و التي تعني أن أفراد العينة مو افقين بدرجة متوسطة على فقرات محور " المشكلات الدر اسية التي تو اجه المر اهقين من وجهة نظر الو الدين ".

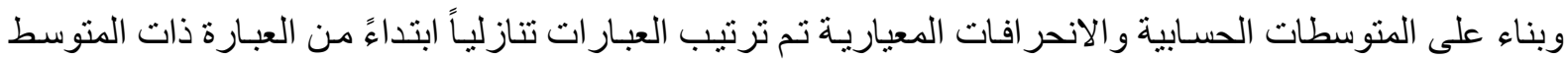
الأكبر و انتهاء بالعبارة ذات المتوسط الأصغر فنجد أن العبارة (بعجز عن تنظيم وتخصيص وقت للار اسـة) بمتوسط بلغ (2.18) ودرجـة مو افقـة منوسطة، ومـن ثم العبـارة (قليـل الاهنمـام بالـدروس و الو اجبـات المنزلية)بمتوسط بلـغ (2.15) ودرجـة مو افقـة متوسطة، تليها العبارة (يشعر بالتوتر النفسي مع اقتر اب مو عد الامتحانات) بمتوسط بلغ (2.07) ودرجة مو افقة متوسطة، ومن ثم العبارة (يذهب متأخر اً للمدرسة) بمتوسط بلغ (1.65) ودرجة مو افقة منوسطة، تليها العبارة (يتمرد على أساتذة المدرسة ولو ائحها النظاميـة) بمنوسط بلغ (1.64) ودرجة مو افقة متوسطة، ومن ثم (كثير الثكوى من زملائه في الفصل) بمنوسط بلـغ (1.65) ودرجة مو افقة ضعيفة.

\section{النتائج المتعلقة بالسؤال الخامس:}

نص السؤال الخامس على" ما هي الآثار المترتبة على الاستقرار الأسري من مشكلات مرحلة المراهقة؟ للإجابة على هذا التساؤل تم استخدام المتوسطات الحسابية والانحر افات المعيارية لعبار ات محور "الاثار المترتبة على الاستقرار الأسري من مشكلات مرحلة المر اهقة" كما يلي:

جدول (4-10) المتوسطات الحسابية والاتحرافات المعيارية لإجابات أفراد العينة على عبارات محور الاثار المترتبة على الاستقرار الأسري من مشكلات مرحلة المر اهقة.

\begin{tabular}{|c|c|c|c|c|c|}
\hline 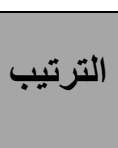 & الموافقة & 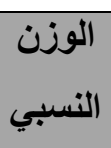 & الانحراف المعياري & 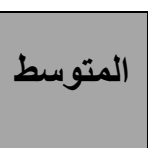 & 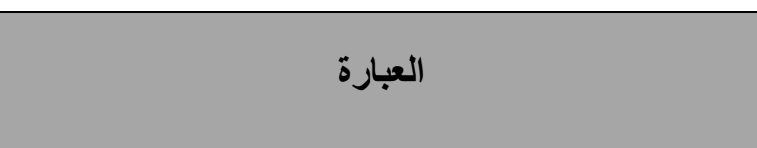 \\
\hline 5 & 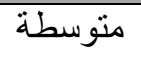 & 76.3 & 0.88 & 2.29 & يتو اصل ابني / ابنتي معي تو اصلاً فُاعلاً. \\
\hline 8 & متوسطة & 67.3 & 0.92 & 2.02 & رأسد إبني / إبنتي صعوبة في التعبير معي عما يدور في \\
\hline 9 & متوسطة & 66.0 & 0.97 & 1.98 & يظهر الضـيق والضـجر على إبنـي/ إبنتـي أثنــاء حديثي \\
\hline
\end{tabular}


المجلة الدولية لنشر البحوث والدراسات

International Journal of Research and Studies Publishing
المجلد الثالث - الإصدار السادس والعشرون تأريخ الإصدار: 20 ديسمبر 2021م

ISSN: 2709-7064

\begin{tabular}{|c|c|c|c|c|c|}
\hline & & & & & מعهף. \\
\hline 11 & متوسطة & 63.0 & 0.90 & 1.89 & يرى إبني / إبنتي أن تو اصلنا معاً مضيعة للوقت. \\
\hline 12 & ضعيفة & 48.7 & 0.77 & 1.46 & يشعر إبني / إبنتي بعدم الأمان داخل الأسرة. \\
\hline 2 & 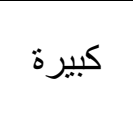 & 83.3 & 0.80 & 2.50 & الأسرٔثر استخدام إيني / إبنتي الهو اتف الذكية على استقرارنا \\
\hline 1 & كبيرة & 93.0 & 0.58 & 2.79 & كلاً منا للأخد الجلسات العائلية مـع إبني / إبنتي على زيادة فهم \\
\hline 3 & كبيرة & 83.3 & 0.82 & 2.50 & يشاركني إبني / إبنتي في الأنشطة و المناسبات الأسرية. \\
\hline 7 & منوسطة & 74.7 & 0.88 & 2.24 & القراقتشـي إبنـي / إبنتـي في أمسور هم الخاصـة قبـل اتخـاذ \\
\hline 10 & متوسطة & 65.3 & 0.93 & 1.96 & لا يتبـادل ابنـي / ابنتي معي وجهـات النظر لحل مشكلة \\
\hline 4 & متوسطة & 77.0 & 0.89 & 2.31 & يتذمر إبني / إبنتي عند تقديم النصح و الإرشاد له. \\
\hline 6 & منوسطة & 75.3 & 0.91 & 2.26 & يتجنب إبني / إبنتي الحديث معي عن مشاكله الخاصة. \\
\hline & متوسطة & 72.78 & 0.85 & 2.18 & 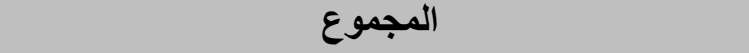 \\
\hline
\end{tabular}

الجدول أعلاه عبـارة عن المتوسطات الحسـابية و الانحر افـات المعياريـة لإجابـات أفر اد العينـة على عبـار ات الآثار

المنرتبـة على الاستقر ار الأسـري مـن مشكلات مرحلـة المر اهقة، فنجد أن المتوسط العـام بلـغ (2.18من 3) بـانحر اف معياري (0.85) و المتوسطات تقع بداخل الفئة الثانية لمعيار ليكرت الثلاثي (1.67 إلى 2.33) و التي تعني أن أفر اد العينـة مو افقين بدرجـة

متوسطة على فقرات محور " الآثار المترتبة على الاستقرار الأسري من مشكلات مرحلة المر اهقة". وبناء على المتوسطات الحسـابية و الانحر افات المعياريـة تم ترتيب العبار ات تنازلياً ابتداءً من العبارة ذات المتوسط الأكبر و انتهاء بالعبارة ذات المتوسط الأصغر فنجد أن العبارة (تساعد الجلسـات العائلية مـع إبني / إبنتي على زيادة فهم كلاً منـا للأخر ) بمتوسط بلغ (2.79) ودرجة مو افقة كبيرة، ومن ثم العبارة (يؤثر استخدام إبني / إبنتي الهو اتف الذكية على استقر ارنا الأسري)بمنوسط بلغ (2.50) ودرجة مو افقة كبيرة، تليها العبارة (يشاركني إبني / إبنتي في الأنشطة والمناسبات الأسرية) بمنوسط بلغ (2.50) ودرجة مو افقة كبيرة، ومن ثم العبارة (يتذمر إبني / إبنتي عند تقديم النصـح والإرشـاد له) بمتوسط بلغ (2.31) ودرجة مو افقة متوسطة، تلبها العبارة (ينو اصل ابني / ابنتي معي تو اصلاً فاعلاً) بمنتوسط بلغ (2.29) ودرجة مو افقة منوسطة، ومن ثم (يتجنب إبني / إبنتي الحديث معي عن مشاكله الخاصـة) بمتوسط بلغ (2.26) ودرجة مو افقة متوسطة، تليها العبارة (يناقثني إبني / إبنتي في أمور هم الخاصـة قبل اتخاذ القر ار) بمتوسط بلغ (2.24) ودرجة مو افقة منوسطة، ومن ثم العبارة (يجد إبني / إبنتي صعوبة في التعبير معي عمـا يدور في رأسه) بمتوسط بلغ (2.02) ودرجة موافقة متوسطة، ومن ثم (يظهر الضيق و الضجر على إبني/ إبنتي أثنـاء حديثي معهم) بمتوسط بلغ (1.98) ودرجة مو افقة متوسطة، ومن ثم العبارة (لا يتبادل ابني / ابنتي معي وجهات النظر لحل مشكلة اسرية) بمتوسط بلغ (1.96) ودرجة مو افقة متوسطة، تليها العبارة (برى إبني / إبنتي أن تو اصلنا معاً مضيعة للوقت) بمتوسط بلغ 
المجلة الدولية لنشر البحوث والدراسات

International Journal of Research and Studies Publishing

ISSN: 2709-7064
المجلد الثالث - الإصدار السادس والعشرون تأريخ الإصدار: 20 ديسمبر 2021م

(1.89) ودرجـة مو افقـة متوسطة، و أخيراً العبارة (يشـعر إبنـي/ إبنتي بعدم الأمـان داخل الأسـرة) بمتوسط بلـغ (1.46) ودرجـة

مو افقة ضعيفة.

\section{4. الفروق بين المتغيرات الشخصية في محاور أداة الدراسة.}

للتعرف على دلالة الفروق في استجابات أفر اد العينة في معرفة ما إذا كان لتقسيمات هذه المتغيرات أثر في الإجابة على الأسئلة، و إلى أي مدى يكون الاختلاف فيما بينها في خيار ات الإجابة، نم استخدام كل من اختبار تحليل التباين الأحادي ANOVA و الذي استخدم مع المتغير ات التي تتقسم إلى ثلاث مجمو عات فأكثر مثل (ترتيب المر اهق بين اخوتـه، المستوى الدراسي العـام للمر اهق، المستوى التعليمي للو الد/ة، الوضع الاقتصادي للأسرة)، واختبار (t) للعينتين المستقلتين Independent sample t-test تستخدم للمتغير ات التي تنقسم فيما بينها إلى مجمو عتين فقط مثل (النوع (ذكر/أنثى)) كما يبين الجدول النالي: جدول رقم (11-4) الفروق بين المتغيرات الثخصية في محاور أداة الدراسة

\begin{tabular}{|c|c|c|c|c|c|c|c|c|c|c|}
\hline \multicolumn{2}{|c|}{ الالار المترتبة على من الأقكلات مرحلة الاسري } & \multicolumn{2}{|c|}{ التي تواجكلات الدراسية المر اهقين } & \multicolumn{2}{|c|}{ 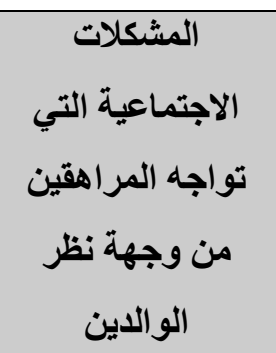 } & \multicolumn{2}{|c|}{ المشكلات النفسية التئ التواجه } & \multicolumn{2}{|c|}{ وجم مشكمة أفراد أسرته المراهت من } & \multirow{2}{*}{ الثتغيرات الثخصية } \\
\hline الدلالة & $\mathrm{T}$ & الدلالة & $\mathrm{T}$ & الدلالة & $\mathrm{T}$ & الدلالة & $\mathrm{T}$ & الدلالة & $\mathrm{T}$ & \\
\hline .130 & 1.857 & .935 & 1.760 & .340 & 1.558 & .720 & -.513 & .775 & 1.277 & النوع \\
\hline $\mathrm{F}$ & الدلالة & $\mathrm{F}$ & الدلالة & $\mathrm{F}$ & الدلالة & $\mathrm{F}$ & الدلالة & $\mathrm{F}$ & الدلالة & \\
\hline 1.472 & .200 & .947 & .451 & 1.641 & .150 & .841 & .522 & 2.550 & .029 & ترتيب المراهق \\
\hline $\mathrm{F}$ & الدلالة & $\mathrm{F}$ & الدلالة & $\bar{F}$ & الدلالة & $\mathrm{F}$ & الدلالة & $\mathrm{F}$ & الدلالة & \\
\hline 2.396 & .093 & 17.860 & .000 & 9.080 & .000 & 7.714 & .001 & 11.613 & .000 & الالمستوى \\
\hline $\mathrm{F}$ & الدلالة & $\mathrm{F}$ & الدلالة & $F$ & الدلالة & $\mathrm{F}$ & الدلالة & $\mathrm{F}$ & الدلالة & \\
\hline 2.159 & .075 & 1.592 & .178 & 1.388 & .239 & .501 & .735 & 3.246 & .013 & اللتوليمي اللـوى \\
\hline $\mathrm{F}$ & الدلالة & $\mathrm{F}$ & الدلالة & $\mathrm{F}$ & الدلالة & $\mathrm{F}$ & الدلالة & $\mathrm{F}$ & الدلالة & \\
\hline .818 & .443 & .156 & .855 & .123 & .884 & 2.603 & .076 & 1.210 & .300 & الاقتصادي \\
\hline
\end{tabular}




\begin{tabular}{|l|l|l|l|l|l|l|l|l|l|}
\hline & & & & & & & & & \\
\hline
\end{tabular}

بينت نتائج الجدول أعلاه أن هناك فروقاً ذات دلالة إحصـائية بين منوسطات ترتيب المر اهقين عند محور (أهم مشكلات المر اهق مع افر اد أسرته من وجهة نظر الو الدين) عند مستوى دلالة إحصائية (0.05). وبينت نتيجة أعلاه أن هناك فروق ذات دلالة إحصائية بين المستويات الدراسية عند المحاور (المشكلات الدر اسية التي تواجـه المر اهقين من وجهة نظر الوالدين، المشكلات الاجتماعية التي تواجه المر اهقين من وجهة نظر الوالدين، المشكلات النفسية التي تو اجه المر اهقين من وجهة نظر الوالدين، أهم مشكلات المر اهق مع افر اد أسرته من وجهة نظر الو الدين) عند مستوى دلالة احصائي (0.05).

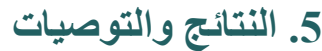
1.5 توصلت الدراسة إلى النتائج التالية: 1- أظهرت النتائج أن أغلب أفر اد العينة من الذكور بنسبة (58.4\%)، و أغلب افر اد العينة ترتيبهم الأول بين أخوتهم بنسبة

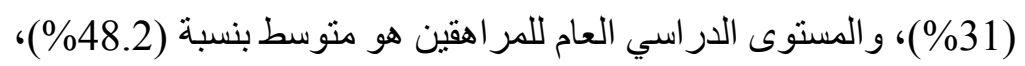
و المستوى التعليمي للو الدين (تعليم جامعي فأعلى) بنسبة (48.2\%)، وبينت النتائج ان الوضع الاقتصـادي للأسرة متوسط بنسبة (81.9\%). 2- أظهرت النتائج أن أهم مشكلات المر اهق مع افر اد أسرته من وجهة نظر الو الدين جـاءت بدرجة متوسطة، وذلك بمتوسط حسـبي بلـغ (2.17) و انحر اف معياري (0.91) وتمثلت أهم هذه المشكلات في أن المر اهق ينفرد بنفسـهـ لوقت طويل، ويثور ويغضب لأتفه الأسباب، ويتحاور مع و الديه بصوت مرتفع، ويستخدم القوة في التعامل مع إخوته، ويرفض مشـاركة أفر اد أسرته في حاجاته، ودائما ما يتو عد اخوته بالانتقام عند حدوث أي خـاف معهم، ويتشـاجر مـع أسرته كثير اً وبشكل مستمر ، ويخر من المنزل مباثرة لمجرد حدوث أي مشكلة. 3- أظهرت النتائج أن أهم المشكلات النفسية التي تواجه المر اهقين من وجهة نظر الو الدين جاءت بدرجة متوسطة، وذلك بمتوسط حسابي بلغ (1.99) و انحر اف معياري (0.88) وتمنلت أهم هذه المشكلات في أن المر اهق يعـاني من سرعة الانفعال و الغضب، ويخاف من انتقاد الآخرين له. 4- أظهرت النتائج أن أهم المشكلات الاجتماعية التي تو اجه المر اهقين من وجهة نظر الو الدين جاءت بدرجة منوسطة، وذلك بمتوسط حسابي بلغ (1.85) و انحر اف معياري (0.89) وتمنلت أهم هذه المشكلات في أن المر اهق يلجأ للكذب للظهور بصورة لائقة أمام الآخرين، ويفتقر للمهار ات الاجتماعية، و عندما يغضب يتلفظ بكلام غير لائق، ويتجنب المشـاركة في الأنشطة الاجتماعية مع الآخرين. 5- أظهرت النتائج أن أهم المشكلات الدر اسية التي تو اجه المر اهقين من وجهة نظر الو الدين جاءت بدرجة منوسطة، وذللك بمتوسط حسـبي بلغ (1.88) و انحر اف معيـاري (0.89) وتمثلت أهم هذه المشكلات في أن المر اهق بعجز عن تنظيم 
المجلة الدولية لنشر البحوث والدراسات

International Journal of Research and Studies Publishing
المجلد الثالث - الإصدار السادس والعشرون تأريخ الإصدار: 20 ديسمبر 2021م

6- أظهرت النتائج أن أهم الآثار المترتبة على الاستقرار الأسري من مشكلات مرحلة المر اهقة جاءت بدرجة منوسطة، وذلك بمتوسط حسابي بلغ (2.18) و انحر اف معياري (0.85) وتمثلت أهم هذه الآثار في أن الجلسـات العائلية هـع إبني / إبنتي تساعد على زيادة فهم كلاً منا للأخر ، ويؤثر استخدام إبني / إبنتي الهو اتف الذكية على استقرارنا الأسري، ويشـاركني إبني / إبنتي في الأنشطة و المناسبات الأسرية، ويتذمر إيني / إبنتي عند تقديم النصح و الإرشـاد له، ويتو اصل ابني / ابنتي معي الهي تو اصلاً فاعلاً، ويتجنب إبني / إبنتي الحديث معي عن مشـاكله الخاصـة، ويناقثني إبني / إبنتي في أمور هم الخاصـة قبل اتخاذ القر ار. 7- أظهرت النتائج وجود فروق ذات دلالة إحصـائية بين منوسطات ترتيب المر اهقين عند محور أهم مشكلات المر اهق مـع

$$
\text { افر اد أسرته من وجهة نظر الو الدين عند مستوى دلالة إحصائية (0.05). }
$$

8- أظهرت النتائج وجود فروق ذات دلالة إحصائية بين المستويات الدر اسية عند المحاور (المشكلات الدر اسية التي تواجـه المر اهقين من وجهة نظر الوالدين، المشكلات الاجتماعية التي نواجه المر اهقين من وجهة نظر الوالدين، المشكلات النفسية

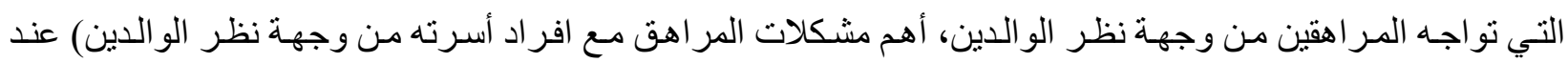

$$
\text { مستوى دلالة احصائي (0.05). }
$$

9- أظهرت النتائج وجود فروق ذات دلالة إحصائية بين المستويات التعليمية للو الدين عند محور (أهم مشكلات المر اهق مع افر اد أسرته من وجهة نظر الو الدين) عند مسنوى دلالة احصائي (0.05).

- 2.5 - التّوصيات. في ضوء ما توصلت إليه الاراسة من نتائج يوصي الباحث بما يأتي: 1- يجب على الآباء والأمهات أن يكون لليهم المعرفة والعلم و الفهم بمشـاعر أبنـائهم المر اهقين وأن يأخذو ها بعين الاعتبار و الاهتمام عند التعامل معهم لما لهذه المرحلة من سمات وخصائص مختلفة، وهنا يأتي دور الإعلام في توعية الأسر بكل ما يتعلق بخصائص هذه المرحلة في حياة أبنائهم، و التطرق لبر امج تتناول هذه المرحلة وما ير افقها من تغيرات.

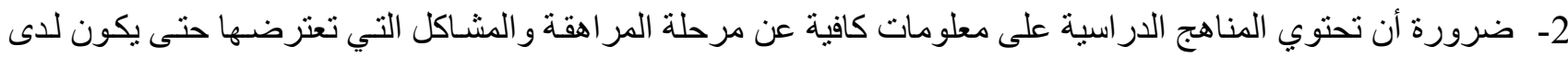
المر اهقين فكرة كافيـة عنها و التغير ات التي تحدث لهم، كذلك وضـع بر امج نوعويـة صحية واجتماعيـة ونفسية وتعليمية مكثفة للمر اهقين في خطط التعليم. 3- ضرورة توفير الدعم النفسي و الاجتماعي والدر اسي و المهني للمر اهقين لمسـاعدتهم على تفهم متطلبات النمو في مرحلة المر اهقة. 4- ضـرورة تزويد المـارس بكو ادر من الأخصـائيين الاجتمـاعبين و النفسيين لدر اسـة مشكلات المـر اهقين ومسـاعدتهم على مواجهنها. 5- ضرورة توثيق العلاقة بين الأسرة و المدرسـة والاستعانة بـآر اء أوليـاء الأمور في حل مشـاكل أبنائهم وخاصـة فيما يتعلق

$$
\text { بالمشكلات الدر اسية. }
$$

6- ضرورة توسيع خبر ات المر اهق ومعار فه الاجتماعية و إكسابه بعض العادات و التقاليد السليمة السائدة في المجتمع. 
المجلة الدولية لنشر البحوث والدراسات

International Journal of Research and Studies Publishing
المجلد الثالث - الإصدار السادس والعشرون تأريخ الإصدار: 20 ديسمبر 2021م

7- توجيه الآبـاء و الأمهات للمزيد من الرعايـة و الاهتمـام بتهيئة الجو الأسرب المناسب لتنشئة الأبناء تنشئة سليمة و إثباع احتياجاتهم. 8- على الآباء والأمهات ترك الحرية للمر اهق في اختيار أصدقائه مع توجيهه إلى حسن اختبار هم و التأكد من سـلامة المعايير السلوكية في مجموعة الأصدقاء التي ينضم اليها.

9- ضـرورة أن نتبع الأسرة الأسـاليب الصـحيحة في تتشئة الأبنـاء المر اهقين وأن تتجنب الأسـاليب التي تعرضهـ للأزمـات الانفعالية ومو اقف الصر اع و الإحباط، كالتخويف و النقد والتفرقة في المعاملة بين الأبناء، أو نقد الأبناء و إظهار هم بمظهر

$$
\text { السخرية والعجز أمام الآخرين. }
$$

10-ضرورة أن يتجنب الآباء والأمهات مو اقف النزاع و المشاجر ات فيما بينهم، لأن ذلك ينعكس على الأبناء المر اهقين بفقدهم الثـعور بـالأمن، وحتى ينمو الأبناء النمو السـليم الخـالي من الاضطر ابات النفسية والتوزع و الانقسام في و لائهم لأحد الو الدين نتيجة لهذه الاختلافات.

3.5 الار اسات المقترحة. 1- القيام بدر اسات مستقبلية تتناول الحاجات النفسية و الاجتماعية و الدر اسية لدى المر اهقين. 2- القيام بدر اسات متعقة لبعض المشكلات التي نواجه المر اهقين و علاقتها بالاستقر ار الأسري بكافة مدن ومناطق المملكة العربية السعودية. 3- إجر اء در اسات متخصصة في كل مجال من مجالات مشكلات المر اهقة مثل: المشكلات الأسـرية، المشكلات الجسـية والجنسية، المشكلات النفسبة، المشكلات التعليميـة، المشكلات الاجتماعيـة، المشكلات السلوكية، المشكلات الاقتصادية - كل على حده.

1- أبو المعاطي، ماهر (2002)، الممارسة العامة في الخدمة الاجتماعية في المجال التعليمي ورعاية الثباب، القاهرة، مركز النشر ونوزيع الكتاب الجامعي، جامعة حلو ان.

2- أبو جادو، صـالح محمد (2004)، علم النفس التطوري، الطفولة والمر اهقة، عمان، ط1، دار الميسر للنشر والتوزيع. 3- أبو سكينة، ناديـة حسن (1992)، عوامل عدم الاستقرار الاسري وأثرهـا على السلوك الاجتمـاعي والاقتصـادي لأطفال المرحلة الابتدائية، در اسة مقارنة، رسالة دكتور اه، كلية الاقتصاد المنزلي، جامعة حلوان. 4- أبو منديل، وسام يوسف (2016)، المشكلات السلوكية و علاقتها بالتو اصل الاسري لدى المر اهقين مستخدمي الهو اتف الذكية من وجهة نظر الو الدين، رسالة ماجستير غير منشورة، الجامعة الاسلامية بغزة. 5- الأشول، عادل عز الدين (1998)، علم نفس النمو، مكتبة الانجلو المصرية، القاهرة. 
6- إمام، ماجدة (2007)، إدر الك الاسرة لأهمية الاستشارة الور اثنية والفحص الطبي قبل الزو اج لاستقر ارهاوسـلامة النسل،

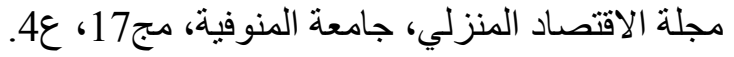
7- أوزي، أحمد (2000)، المر اهق وحاجاته النفسية، وزارة التربية و التعليم، مملكة البحرين. 8- البدري، صلاح الدين (2008)، و اقع مشكلات المر اهقة للى طلبـة المرحلة الثانويـة التخصصية بمدينة طر ابلس، رسـالة ماجستير غير منشورة، جامعة الفاتح، ليبيا.

9- بيومي، محمد حسن (2002)، در اسات معاصرة في سيكولوجية الطفولة و المر اهقة، القاهرة، مكتبة زهر ان الثرق. 10 - توفيق، سميحة كرم (1996)، مدخل الى العلاقات الاسرية، مكتبة الانجلو المصرية، القاهرة. 11- توفيق، محمد نجيب (1998)، البحث الاجتماعي ونماذج تطبيقه في الخدمة الاجتماعية، القاهرة، كلبـة لخدمة الاجتماعية، حلوان.

12- جلال، أحمد سعد (2007)، مشكلات المر اهقة الاكثر شيو عاً من وجهة نظر المعلمات: در اسة مقارنة بين طالبات المرحلة الثانوية في كل من سلطنة عمان ومملكة البحرين، ملجة در اسات الطفولة، مج 10، ع34، ص ص ص 79-95. 13ـ الحافظ، نوري (1990)، المر اهق، المؤسسة العربية للار اسات و النشر، ط2، بيروت، لبنان. 14ـ الحسن، احسان محمد (1999)، موسو عة علم الاجنماع، الدار العربية للموسوعات، بيروت. 15- حسن، عبد الباسط محمد (1999)، أصول البحث الاجتماعي، مكتبة وهبة. 16- دسوقي، كمال (1998)، النمو التربوي للطفل و المر اهق، دار النهضة العربية، القاهرة. 17- الدليمي، طارق (2012)، الاسرة ودور ها التربوي أمام تحديات العولمـة، مجلة جرش للبحوث و الدر اسـات، 14 (2) ص $.325-306$

18ـ الرفاعي، ردينا إبر اهيم (2017)، صور الزوج المستحدثة وأثر ها على الاستقرار الاسري، المجلة الأردنيـة في الدراسـات

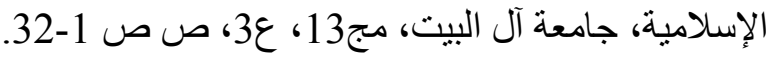
19- الزر اد، فيصل محمد (1997)، مشكلات المر اهقة و الثباب، بيروت، دار النفائس للطباعة و النشر. 20- زهران، حاهد (1971)، علم النفس النمو، عالم الكتب. 21- زهر ان، حامد عبد السلام (1995)، علم النفس النمو، ط5، عالم الكتب للنشر، القاهرة. 22- السكري، أحمد شفيق (2000)، قاموس الخدمة الاجتماعية والخدمات الاجتماعية، الاسكندرية، دار المعرفة الجامعية. 23- سليم، مريم (2002)، علم نفس النمو، ط1، بيروت، دار النهضة العربية. 24- سـليمان، سـناء محمد(2005)، التو افق الزواجي واستقر ار الاسـرة مـن منظور إسـلامي نفسـي اجتمـاعي، عـالم الكتب،

25- الثباني، عمر (1998)، الأسس النفسية لرعاية الشباب، طر ابلس، الدار العربية للكتاب، ط3 ـ 26- شحاته، جمال (2005)، الخدمـة الاجتماعية في مجـال رعايـة الثباب و المجـال المدرسي، القاهرة، مركز مشر وتوزيع الكتاب الجامعي، حلوان. 27- شريم، رغدة (2009)، سيكولوجية المر اهقة، عمان، دار المبيرة للنشر و التوزيع. 
المجلة الدولية لنشر البحوث والدراسات

International Journal of Research and Studies Publishing
المجلد الثالث - الإصدار السادس والعشرون تأريخ الإصدار: 20 ديسمبر 2021م

28- الثيباني، عمر (1997)، مناهج البحث الاجتماعي، طر ابلس، منشأة النشر و التوزيع و الاعلان.

29- صحاف، خلود (2014)، التو افق الزواجي وعلاقته بالاستقر ار الأسـري لدى عينـة من المتزوجين بمكة المكرمـة، رسـالة

$$
\text { ماجستير غير منشورة، جامعة أم القرى. }
$$

30- ضميرية، عثمان جمعة (2009)، الاسرة وتربية الأبناء في مرحلة المر اهقة، شئون اجتماعية، مـ 26، ع101، ص ص ص

$.230-201$

31- الطواب، سيد محمود (1998)، النمو الإنساني أسسه وتطبيقاته، دار المعرفة الجامعية، القاهرة. 32- العتوم، روان (2019)، علاقة الاهل بالمر اهق، مقال متاح عبر موقع عربي على الر ابط التالي دttps://e3arabi.com. 33- عطا، محمود (1997)، النمو الإنساني (الطفولة والمر اهقة)، ط2، الرياض، دار الخريجين للنشر والتوزيع. 34- العطار، سميرة عادل (2001)، علم الاجتماع العائلي، كلية البنات، جامعة عين شمس.

35- عفيفي، عبد الخالق محمد (2002)، الاسرة المصرية والمر اهقة، مجلة الخدمـة الاجتماعية، مج20، ع46، ص ص 73-

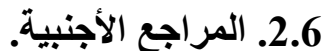

1- David Paul Ausubel: Theory and problems of adolescent 40 development, Grune \& Stratton, 1954.

Doi: $\underline{\text { doi.org/10.52133/ijrsp.v3.26.6 }}$ 